\title{
Research Square \\ Removal of NO With Fe(II)NTA Solution Catalyzed By The Carbon Treated With Ethylenediamine
}

\section{Xin-wei Dou}

East China University of Science and Technology

\section{Pei-yun Chen}

East China University of Science and Technology

\section{Ruo-chuan Zhang}

East China University of Science and Technology

Xiangli Long ( $\square$ longdragon@ecust.edu.cn )

East China University of Science and Technology

\section{Research Article}

Keywords: activated carbon, catalysis, $\mathrm{Fe}(\mathrm{\bigotimes}) \mathrm{NTA}$, nitric oxide, ethylenediamine

Posted Date: May 13th, 2021

DOI: https://doi.org/10.21203/rs.3.rs-360602/v1

License: (c) (i) This work is licensed under a Creative Commons Attribution 4.0 International License. Read Full License 


\title{
Removal of NO with Fe( II )NTA solution catalyzed by the carbon
}

\section{treated with ethylenediamine}

\author{
Xin-wei Dou, Pei-yun Chen, Ruo-chuan Zhang and Xiang-li Long* \\ State Key Laboratory of Chemical Engineering, School of Chemical Engineering, \\ East China University of Science and Technology, Meilong Road 130, Shanghai 200237, People's Republic of China
}

\begin{abstract}
Fe}(\mathrm{II}) \mathrm{NTA}$ solution manifests a good performance in the simultaneous removal of sulfur dioxide and nitric oxide. Activated carbon is used to catalyze the reduction of Fe(III)NTA to Fe( II )NTA to retain the ability of absorbing NO. Ethylenediamine(EDA) solution is capable of changing the physical structure and chemical characteristics on the carbon surface to improve the catalytic capability of activated carbon. The experiments suggest that the best treatment condition be immersing the carbon in $5.0 \mathrm{~mol} \mathrm{l}^{-1}$ EDA solution for $6 \mathrm{~h}$ followed by being heated at $700{ }^{\circ} \mathrm{C}$ in $\mathrm{N}_{2}$ for $4 \mathrm{~h}$. The modification with EDA increases the surface area and alkalinity on the carbon. The experiments also indicate that the removal efficiency of nitric oxide catalyzed by the modified carbon is significantly improved compared with that of the original one.
\end{abstract}

Keywords: activated carbon, catalysis, Fe( II )NTA, nitric oxide, ethylenediamine

\section{Introduction}

The emissions of sulfur dioxide and nitric oxide are causing a series of environmental problems such as acid rain, ozone layer destruction, photochemical smog, and even endangering human health(Toro et al. 2014; Saikawa et al. 2017; Ma et al. 2017). Faced with the severe impact of these pollutants, and more and more stringent national emission requirements, various technologies have been developed to control the emission of $\mathrm{SO}_{2}$ and $\mathrm{NO}_{\mathrm{x}}$. Wet flue gas desulfurization (FGD) is the most popular technology used for $\mathrm{SO}_{2}$ removal due to its excellent performance in commercial application[4-5](Dou et al. 2009; Zheng et al. 2014). However, this approach is incapable of eliminating $\mathrm{NO}_{\mathrm{x}}$ since $90-95 \%$ of the $\mathrm{NO}_{\mathrm{x}}$ in typical flue gases is the water-insoluble nitric oxide (NO). In order to solve this problem, some oxidants have been used to transform NO into soluble $\mathrm{NO}_{2}$ (Pan et al. 2015; Yan et al. 2018; Kang et al.2020; Guo 2018; Liémans and Thomas 2013; Mondal and Chelluboyana 2013; Khan and Adewuyi 2010) However, the oxidation of NO by chemical agents has not been applied commercially yet due to their high costs and the production of large amounts of waste water. The SCR technology is most widely used in coal-fired power plants to complete the reduction of nitric oxide in the flue gases. But this technology suffers the disadvantage of high capital and operating costs( Tang et al. 2020). Hence there is an urgent need to develop a low-cost, easily- industrialized method of denitrification.

${ }^{*}$ Corresponding author, Professor Xiang-li Long, Tel.: +86 21 6425 3267; fax: +86 216425 3528; E-mail: longdragon@ecust.edu.cn (X. L. Long), State-Key Laboratory of Chemical Engineering, East China University of Science and Technology, Shanghai, 200237, P. R. China. 
The low solubility of NO in water can be avoided effectively by binding NO with complexants. Such liquid-phase complex method has a broad industrial application prospect because it holds the advantages of high denitrification efficiency, fast reaction rate and small equipment input. The approach that introduces $\mathrm{Fe}($ II )(NTA) (NTA, nitrilotriacetic acid) or Fe( II )(EDTA)(EDTA, ethylenediaminetetraacetate) into the scrubbing liquor to enhance the solubility of $\mathrm{NO}$ via the formation of $\mathrm{Fe}(\mathrm{II})(\mathrm{NTA}) \mathrm{NO}$ or Fe( II )(EDTA)NO has been studied extensively(Hofeleet al.1996; Chandrashekhar et al.2015; Chandrashekhar et al. 2013; Zhu et al. 2010). Compared with EDTA, NTA holds several advantages such as smaller molecular weight and less toxicity. Furthermore, the complex Fe( II )(NTA)NO, is less stable than $\mathrm{Fe}$ (II )(EDTA)NO(Wolak and van Eldik 2002), which is helpful to the reduction of $\mathrm{NO}_{\text {to }} \mathrm{N}_{2}$. Although Fe( II )(NTA) can obtain a high NO removal efficiency, it is easily oxidized to Fe(III)(NTA) that is not capable of binding NO. Activated carbon can speed up the regeneration of Fe( II )(NTA) with sulfite/bisulfite as a reductant to maintain the NO removal efficiency so as to realize the simultaneous removal of $\mathrm{SO}_{2}$ and $\mathrm{NO}$ from flue gas streams for a long period. The combined elimination of NO and $\mathrm{SO}_{2}$ can be described briefly as follow.

$\mathrm{Fe}(\mathrm{II})(\mathrm{NTA})$ may react with dissolved NO according to the following equations:

$$
\mathrm{NO}(\mathrm{g}) \rightarrow \mathrm{NO}(\mathrm{aq})
$$

$$
N O(l)+\mathrm{Fe}(\mathrm{II}) \mathrm{NTA}^{-} \longleftrightarrow \mathrm{Fe}(\mathrm{II}) \mathrm{NTA}(\mathrm{NO})^{-}
$$

In the meantime, the $\mathrm{SO}_{2}$ existing in the gas stream also dissolves into the aqueous solution:

$$
\begin{aligned}
& \mathrm{SO}_{2}+\mathrm{H}_{2} \mathrm{O} \rightarrow \mathrm{SO}_{3}^{2-}+2 \mathrm{H}^{+} \\
& \mathrm{SO}_{2}+\mathrm{H}_{2} \mathrm{O}+\mathrm{SO}_{3}^{2-} \rightarrow 2 \mathrm{HSO}_{3}^{-}
\end{aligned}
$$

However, the oxygen coexisting in the flue gases may oxidize Fe(II)(NTA)- to Fe(III)(NTA)(Eq.(5)) during the gas scrubbing. NO removal efficiency will decrease quickly as the operation proceeds due to the decline of $\mathrm{Fe}(\mathrm{II})(\mathrm{NTA})$ concentration.

$$
\mathrm{Fe}(I I)(N T A)^{-}+\mathrm{O}_{2}+4 \mathrm{H}^{+} \longrightarrow 4 \mathrm{Fe}(I I I)(\mathrm{NTA})+2 \mathrm{H}_{2} \mathrm{O}
$$

To retain the NO removal efficiency, activated carbon can be used as a catalyst and the sulfite/bisulfite ions produced by $\mathrm{SO}_{2}$ absorption into the aqueous solution act as reductants to regenerate Fe(II)(NTA)The mechanism of Fe(III)(NTA) catalytic reduction can be expressed as follows:

The Fe(III)NTA adsorbed on the carbon surface disintegrates into Fe(III) and NTA:

$$
A C+F e(I I I) N T A \longleftrightarrow A C \Lambda \mathrm{NTA}+F e(I I I)
$$

Electrochemical half-cell reduction potential of $\mathrm{Fe}(\mathrm{III}) / \mathrm{Fe}(\mathrm{II})(\mathrm{Eq}(7))$ exhibits that $\mathrm{Fe}(\mathrm{III})$ is a strong oxidant and can be reduced to Fe(II) easily. 


$$
F e(I I I)+e^{-}=F e(I I) \quad E_{F e(I I I) / F e(I I)}=0.71 V
$$

The net reaction for the regeneration of $\mathrm{Fe}(\mathrm{II})$ ions can be written as follow:

$$
2 \mathrm{Fe}(\mathrm{III})+\mathrm{SO}_{3}^{2-}+\mathrm{H}_{2} \mathrm{O} \stackrel{\mathrm{AC}}{\rightarrow} \mathrm{SO}_{4}^{2-}+2 \mathrm{Fe}(\mathrm{II})+2 \mathrm{H}^{+}
$$

$\mathrm{Fe}(\mathrm{II})(\mathrm{NTA})$ is regenerated by $\mathrm{Fe}(\mathrm{II})$ coordinating with NTA(Eq. (9)). Therefore, the NO removal efficiency can be sustained for a long time.

$$
\mathrm{Fe}(\mathrm{II})+N T A^{3-} \longrightarrow F e(I I) N T A^{-}
$$

Besides, the NO coordinated with $\mathrm{Fe}(\mathrm{II})(\mathrm{NTA})$ may be reduced to $\mathrm{N}_{2} \mathrm{O}$ by sulfite.

$$
\mathrm{Fe}(\mathrm{II})(\mathrm{NTA})(\mathrm{NO})^{2-}+\mathrm{SO}_{3}^{2-} \rightarrow 2 \mathrm{Fe}(\mathrm{II})(\mathrm{NTA})^{2-}+\mathrm{N}_{2} \mathrm{O}+\mathrm{SO}_{4}^{2-}
$$

Nitrous oxide is also a harmful pollutant that contributes to the depletion of the ozone layer(Ravishankara et al. 2009). It has been reported that $\mathrm{N}_{2} \mathrm{O}$ can be reduced to $\mathrm{N}_{2}$ by $\mathrm{CO}$ under the catalytic action of carbon(Chen et al. 2019). In the process discussed in this paper, $\mathrm{N}_{2} \mathrm{O}$ can be further reduced to $\mathrm{N}_{2}$ by sulfite/bisulfite under the catalysis of activated carbon.

$$
\mathrm{SO}_{3}^{2-}+\mathrm{N}_{2} \mathrm{O} \stackrel{\mathrm{AC}}{\rightarrow} \mathrm{SO}_{4}^{2-}+\mathrm{N}_{2}
$$

According to the discussion above, this technology realizes not only the absorption and reduction of nitric oxide but also the absorption and oxidation of sulfur dioxide.

Activated carbon plays an important role in the process of regeneration of $\mathrm{Fe}(\mathrm{II})(\mathrm{NTA})$. The catalytic activity of activated carbon is dependent on its surface characteristics. By transforming the physical structure and chemistry characteristics on the carbon surface, the capabilities of activated carbon may be improved to a certain extent. Wang et al.( Wang et al. 2019) treated the activated carbon to upgrade isophthalic acid yield from the oxidation of m-xylene under the catalysis of phosphotungstic acid loaded on the activated carbon. Zhang et al.(Zhang et al. 2016) found that the thermal modification can enhance phenol adsorption on carbon samples. Fu et al.(Fu et al, 2016) reported the introduction of amino groups enhanced the adsorption capacity of heavy metals. Zhang et al.(Zhang et al. 2016) prepared a kind of activated carbon with well-developed micropore structure and abundant basic nitrogen-containing functionalities by $\mathrm{KOH}$ activation and ammonia modification. Zheng et al.( Zheng et al. 2019) used dicyandiamide to dope activated carbon with nitrogen.

Ethylenediamine is a strong alkaline with nitrogen content of $46.6 \%$. It may combine with the acidic groups, such as carboxyl groups, as follow(Li et al. 2009):

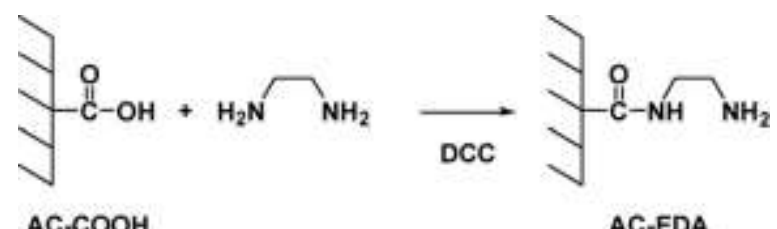

The N-containing groups on the surface increases the electronic density and the basicity of the activated 
carbon(Messele et al. 2014). Li et al(Li et al. 2009) performed a study on the modification of activated carbon with ethylenediamine for selective solid-phase extraction and preconcentration of metal ions. Messele et al.(Messele et al. 2014) found that the carbon modified with ethylenediamine significantly enhanced phenol removal efficiency. $\mathrm{Fu}$ et al.(Fu et al. 2016) treated the activated carbon with ethylenediamine to enhance the adsorption capability for $\mathrm{Cr}(\mathrm{VI})$. In this paper, ethylenediamine solution has been tried to treat the activated carbon of coconut to promote its catalytic capacity in the regeneration of $\mathrm{Fe}(\mathrm{II})(\mathrm{NTA})$ in order to obtain higher NO removal efficiency.

\section{Experimental}

\subsection{Materials}

The coconut activated carbon purchased from Shanghai Activated Carbon Co., Ltd, was purged with deionized water and then dried at $110{ }^{\circ} \mathrm{C}$ in a vacuum for $24 \mathrm{~h}$. Carbon samples of $100 \sim 120$ mesh were prepared before being used as catalysts or modified with EDA solution. The carbon was dealt with EDA solution in the following steps: Firstly, $5 \mathrm{~g}$ activated carbon was impregnated in $250 \mathrm{~mL}$ EDA solution for several $\mathrm{h}$ at room temperature; secondly, after being filtrated, the carbon sample was put in a vacuum drying oven at $110{ }^{\circ} \mathrm{C}$ for $12 \mathrm{~h}$; thirdly, the samples obtained were heated under $\mathrm{N}_{2}$ atmosphere in a furnace at set temperature for a few $h$.

\subsection{Reduction of Fe(III)NTA}

The experiments to test the catalytic capability of the carbon samples in the reduction of Fe(III)NTA were carried out in a stirred glass flask of $250 \mathrm{ml}$ with a turbine impeller of diameter $3 \mathrm{~cm}$ mounted on the bottom of the stirring rod. The stirring speed was $300 \mathrm{rpm}$. When the temperature of the solution reached $70{ }^{\circ} \mathrm{C}, 1.0 \mathrm{~g}$ activated carbon and $3.15 \mathrm{~g} \mathrm{Na}_{2} \mathrm{SO}_{3}$ were added sequentially into the glass flask filled with $200 \mathrm{ml} 0.01 \mathrm{~mol} \mathrm{~L}^{-1} \mathrm{Fe}(\mathrm{III}) \mathrm{NTA}$ solution. In the course of the experiments, $1.0 \mathrm{~mL}$ liquid sample was taken from the flask every few min into a $100 \mathrm{~mL}$ volumetric flask containing $5 \mathrm{~mL} 0.025 \mathrm{~mol} \mathrm{~L}^{-1}$ phenanthroline solution, $5 \mathrm{~mL}$ pH 2.9 glycine solution and $1 \mathrm{~mL} 0.1 \mathrm{~mol} \mathrm{~L}^{-1} \mathrm{NTA}$ solution. And then the liquid in the volumetric flask was raised to $100 \mathrm{ml}$ by adding deionized water. The $\mathrm{Fe}^{2+}$ concentration was measured with a spectrophotometer at $25^{\circ} \mathrm{C}$ from the absorbance at $510 \mathrm{~nm}$. The Fe(II) calibration curve was obtained using standard $\mathrm{FeSO}_{4} \cdot 7 \mathrm{H}_{2} \mathrm{O}$ solutions ranged from 0.00 to $0.12 \mathrm{mmol} \mathrm{L}{ }^{-1}$. Least-squares fits to the data yield Eq. (13) with a correlation coefficient $\left(r^{2}\right) 0.9998$.

$$
\mathrm{C}=10.888 \text { A- } 0.0006
$$

where A stands for absorbency and $\mathrm{C}$ for $\mathrm{Fe}(\mathrm{II})$ concentration $\left(10^{-3} \mathrm{~mol} \mathrm{~L}^{-1}\right)$.

$\mathrm{Fe}(\mathrm{III})$ concentration was computed from the difference between total iron and $\mathrm{Fe}(\mathrm{II})$. Fe(III)NTA] conversion $\left(\mathrm{X}_{\mathrm{Fe}(\mathrm{III}) \mathrm{NTA}} \%\right)$ is determined as follow:

$$
\mathrm{X}_{F e(I I I) N T A} \%=\frac{C_{F_{\text {etota }}}-C_{F e(I I I)}}{C_{F e_{\text {tota }}}}=\frac{C_{F e(I I)}}{C_{F e_{\text {tota }}}} \times 100
$$

Where $C_{F_{\text {tota }}}, C_{F e(I I I)}$ and $C_{F e(I I)}$ are the total iron, $\mathrm{Fe}(\mathrm{III})$ concentration and $\mathrm{Fe}(\mathrm{II})$ concentration at $\mathrm{t}$ 
time in the solution, respectively.

\subsection{Combined removal of $\mathrm{NO}$ and $\mathrm{SO}_{2}$}

The schematic diagram of the experimental apparatus for the simultaneous removal of $\mathrm{NO}$ and $\mathrm{SO}_{2}$ is shown in Fig. 1 The absorption was performed in a packed tower (18 mm i.d., $1000 \mathrm{~mm}$ long) and the $\mathrm{Fe}(\mathrm{II}) \mathrm{NTA}^{-}$regeneration was carried out in a fixed-bed $(20 \mathrm{~mm}$ i.d.) reactor packed with $20 \mathrm{~g}$ activated carbon of 20-40 mesh. The temperature of the absorber and regeneration tower was controlled at $50{ }^{\circ} \mathrm{C}$ by the jackets through which water from thermostatic baths was recycled. Five hundred milliliter $\mathrm{Fe}$ (II)NTA- solution together with measured amount of $\mathrm{Na}_{2} \mathrm{SO}_{3}$ was added into the circulation tank. The $\mathrm{pH}$ was controlled at 5.5 using $\mathrm{NaOH}(1.0 \mathrm{~mol} / \mathrm{L})$ solution by a THORNTON M300 pH/ORP transmitters as well as a pH-electrode in the course of the experiment. The absorber was operated with a continuous gas stream feeding at $270 \mathrm{ml} \mathrm{min}{ }^{-1}$ from the bottom and a continuous scrubbing solution feeding at $25 \mathrm{ml}$ $\mathrm{min}^{-1}$ from the top. The absorbent discharging from the packed tower was fed into the circulation tank. When the regeneration of $\mathrm{Fe}$ (II)NTA- started, the absorbent in the circulation tank ran through the regeneration reactor upwardly and into the packed tower to scrub $\mathrm{NO}$ and $\mathrm{SO}_{2}$ directly after it left the regeneration reactor. The experiment was performed under atmospheric pressure.

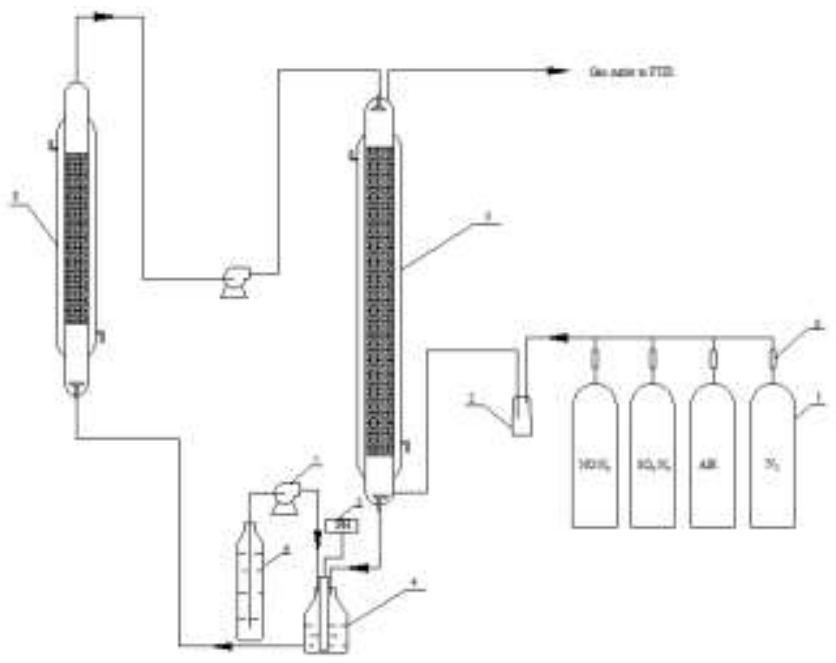

Fig.1 Flowchart of absorption and regeneration reactor system

1-Cylinder; 2-buffer tank; 3-packed column; 4-circulation tanker; 5-pH meter; 6-NaOH solution; 7-pump; 8-regeneration reactor; 9-massmeter

The quantitative analysis of gas compositions was achieved by an on-line Fourier transform infrared spectrometer (Nicolet E.S.P. 460 FT-IR) equipped with a gas cell and a quantitative software package, named Quant Pad. The length of the gas cell in the FTIR is $2 \mathrm{~m}$. The peaks in the region 1150-1200 $\mathrm{cm}^{-1}, 2850-2935 \mathrm{~cm}^{-1}, 2150-2225 \mathrm{~cm}^{-1}$ and $1875-1960 \mathrm{~cm}^{-1}$ were applied to identify $\mathrm{SO}_{2}, \mathrm{NO}_{2}, \mathrm{~N}_{2} \mathrm{O}$ and NO, respectively. The inlet and outlet gases moved directly into the gas cell of the FTIR to obtain the transient $\mathrm{N}_{2} \mathrm{O}, \mathrm{NO}, \mathrm{NO}_{2}$ and $\mathrm{SO}_{2}$ concentrations in both the inlet and outlet gases, as well as the transient NO conversion. The heights of the peaks are proportional to the concentrations of the components to be 
detected and the relative standard deviations of the measurements were determined to be within $1 \%$. Hence this set-up is feasibly and conveniently operated to monitor the $\mathrm{NO}$ and $\mathrm{SO}_{2}$ removal efficiency.

\subsection{Characterization of carbon samples}

FT-IR was used to analyze the functional groups on the surface of activated carbon by $\mathrm{KBr}$ compression method(O'reilly and Mosher 1983) and the point of zero charge $\left(\mathrm{pH}_{\mathrm{pzc}}\right)$ was determined by mass titration.. An ASAP2020 surface Analyzer(Micromeritics Co. USA) was used to measure the specific surface area of activated carbon with nitrogen as adsorption medium at $77 \mathrm{~K}$. The total surfaces of the carbon samples were calculated by BET method. The surface area and volume of mesopores were obtained by BJH method, and the micropores of which were computed by t-plot method. The content of acidic and basic functional groups on the surface of activated carbon were measured by Boehm titration(Boehm 1994). XPS was characterized by an ESCALAB 250 electron spectrometer from Thermo Corporation with $300 \mathrm{~W}$ AlK $\alpha$ radiation at the base pressure of $3 \times 10^{-9}$ mbar.

\section{Results and discussion}

\subsection{Effect of ethylenediamine concentration}

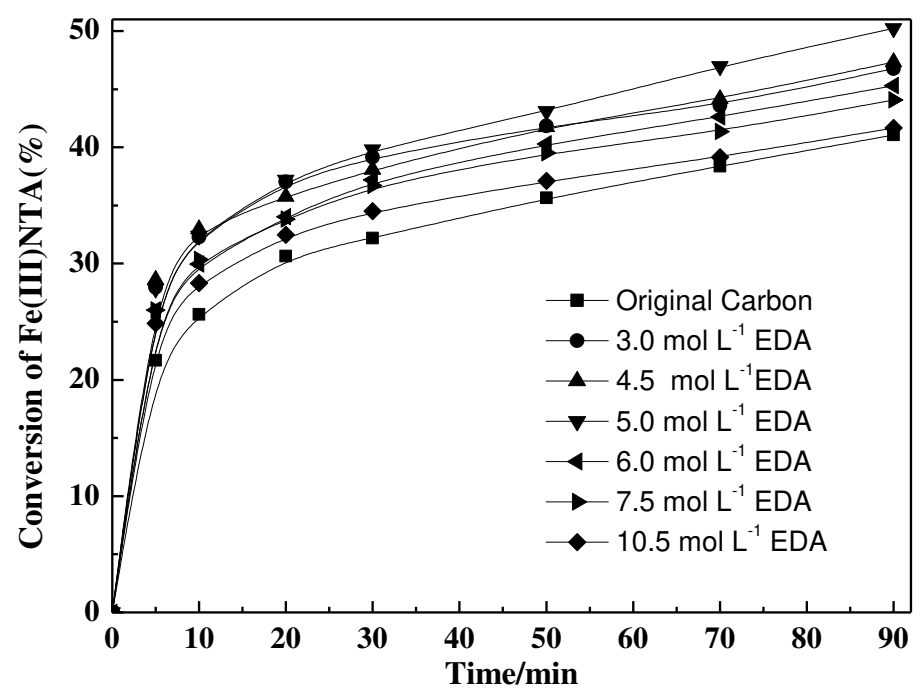

Fig. 2 Effect of the EDA concentration on the catalytic performance of carbon samples

$[\mathrm{Fe}(\mathrm{III}) \mathrm{NTA}]=0.01 \mathrm{~mol} \mathrm{~L}^{-1}, \mathrm{SO}_{3}{ }^{2-}=0.1 \mathrm{~mol} \mathrm{~L}^{-1}, \mathrm{pH}=6.17,300 \mathrm{rpm}, 70^{\circ} \mathrm{C}$

To explore the effect of EDA concentration on the catalytic capacity of the activated carbon, six carbon samples were impregnated in EDA solutions with a concentration of $3.0 \mathrm{~mol} \mathrm{~L}^{-1}, 4.5 \mathrm{~mol} \mathrm{~L}^{-1}, 5.0$ mol L${ }^{-1}, 6.0 \mathrm{~mol} \mathrm{~L}^{-1}, 7.5 \mathrm{~mol} \mathrm{~L}^{-1}$ and $10.5 \mathrm{~mol} \mathrm{~L}^{-1}$, respectively, for $6 \mathrm{~h}$ at ambient temperature. And then they were heated in $\mathrm{N}_{2}$ at $800{ }^{\circ} \mathrm{C}$ for $4 \mathrm{~h}$. The prepared samples were used to catalyze the reduction of $\mathrm{Fe}(\mathrm{III}) \mathrm{NTA}$ at $70{ }^{\circ} \mathrm{C}$. The conversions of $\mathrm{Fe}$ (III)NTA presented in Fig.2 prove that the catalytic performance of the activated carbon is ameliorated after the carbon is treated with EDA solution. After 90 min's operation, the Fe(III)NTA conversion got by the original carbon is $41.07 \%$ while those acquired by 
the one treated with 3.0, 4.5, 5.0, 6.0, 7.5 and 10.5 mol L ${ }^{-1}$ EDA solution are 46.76, 47.34, 50.24, 45.32, 44.06 and $41.07 \%$, respectively. As a result, the best EDA concentration for the carbon modification is $5.0 \mathrm{~mol} \mathrm{~L}^{-1}$.

The reason for the improvement in the catalytic ability of the carbon samples treated with EDA solution may be given according to the change of its surface characteristics.

The carbon samples were detected by FTIR to analyze their surface chemistry. The FTIR transmission spectrum of the original carbon and the one soaked in $5.0 \mathrm{~mol} \mathrm{~L}^{-1}$ EDA solution are shown in Fig.3. According to the literatures(Allwar 2012; Chen et al. 2014), the absorption peak observed at 3430 $\mathrm{cm}^{-1}$ in the FTIR spectra is resulted from hydroxyl $\mathrm{O}-\mathrm{H}$ and adsorbed $\mathrm{H}_{2} \mathrm{O}$ on the carbon surface. The band exhibited at $2919 \mathrm{~cm}^{-1}$ is ascribed to the stretching vibration of the hydrocarbon single bond C-H. The carbonyl absorption peak from lactonic and carboxyl is exhibited at $1625 \mathrm{~cm}^{-1}$. The peak at 1089 $\mathrm{cm}^{-1}$ is due to the phenolic -OH group and C-O group. It can be seen from Fig.3 that the overall shapes of these two spectra are very similar, which suggests they hold the similar chemical characteristics. The strength of the peaks at $3430 \mathrm{~cm}^{-1}$ and $1089 \mathrm{~cm}^{-1}$ become weaker after the carbon has been treated with EDA solution. The summary that there is no new functional group produced and the amount of hydroxyl as well as the content of ester group or ether bonds decrease can be made.

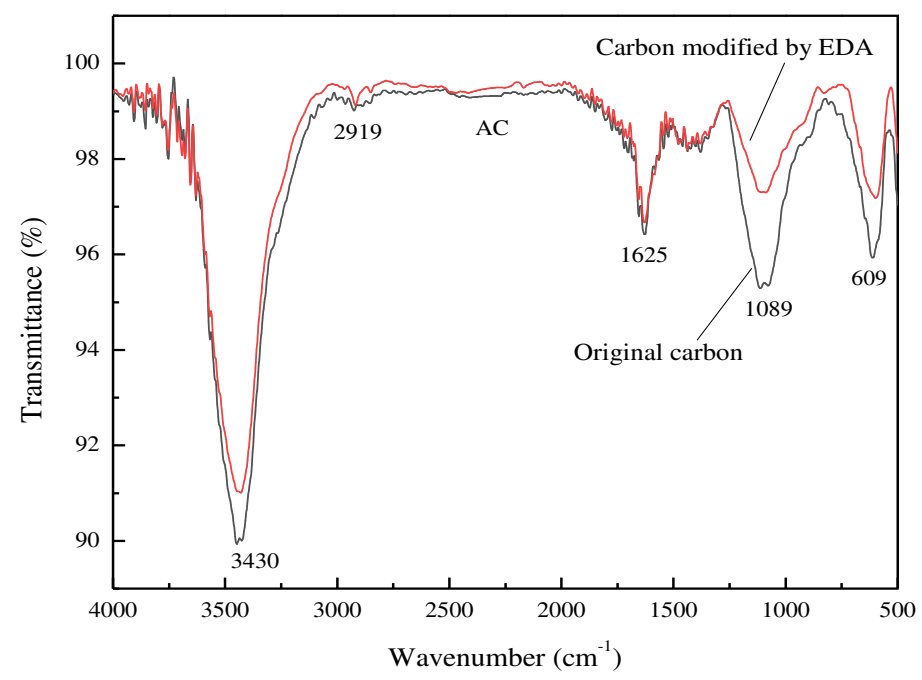

Fig.3 FTIR spectra of original carbon and modified carbon with EDA

XPS characterization has been made for the original one and the one immersed in $5.0 \mathrm{~mol} \mathrm{~L}^{-1} \mathrm{EDA}$ solution. The XPS C 1s spectra shown in Fig.4 are resolved into several individual component peaks. The molar percentages based on the peak resolution are illustrated in Table 1. The data listed in Table 1 indicates that the molar percentage of graphitic carbon on the carbon surface increases from $70.07 \%$ to $71.70 \%$ after being modified with EDA solution. The percentage of the carbon in phenolic, alcohol or ether groups decreases slightly (from $8.97 \%$ to $8.47 \%$ ) after the carbon treated by EDA solution. The carbon in carbonyl or quinine groups reduces imperceptibly from $7.41 \%$ to $7.22 \%$. The $\mathrm{C}$ in lactonic or 

the carbon.
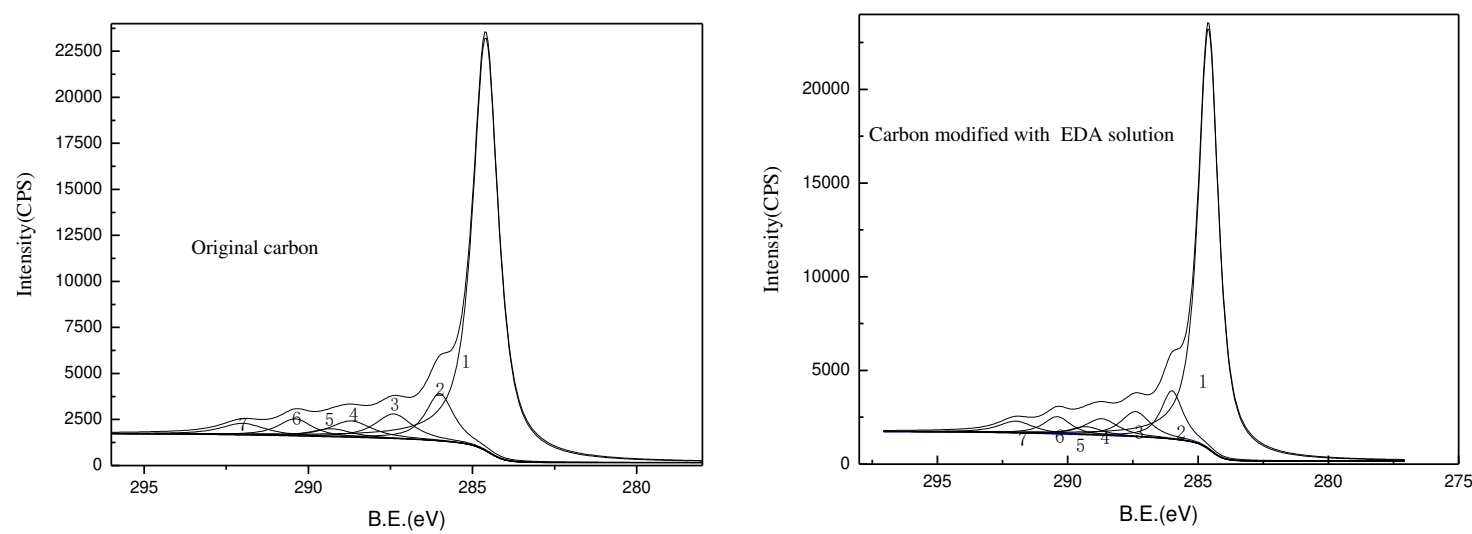

Fig. 4 C1s spectra of the original carbon and the modified carbon

Table 1 Fitted C1s peak parameters deduced from XPS for carbon samples

\begin{tabular}{ccccc}
\hline Peaks & $\begin{array}{c}\text { B.E } \\
(\mathrm{eV})\end{array}$ & Assignment & $\begin{array}{c}\text { Original carbon } \\
(\boldsymbol{\%})\end{array}$ & $\begin{array}{c}\text { Carbon modified } \\
(\%)\end{array}$ \\
\hline 1 & 284.6 & C=C & 70.07 & 71.70 \\
2 & 286.0 & C-OH, C-O-C, C-O-R & 8.97 & 8.48 \\
3 & 287.4 & C-N, C=O & 7.41 & 7.22 \\
4 & 288.7 & C=N-, -N=C-O-, COOC- & 5.16 & 4.75 \\
5 & 289.3 & COOH & 2.31 & 0.92 \\
6 & 290.4 & $\pi \rightarrow \pi^{*}$ shake-up satelite & 3.54 & 3.97 \\
7 & 292.0 & Plasmon & 2.54 & 2.96 \\
\hline
\end{tabular}
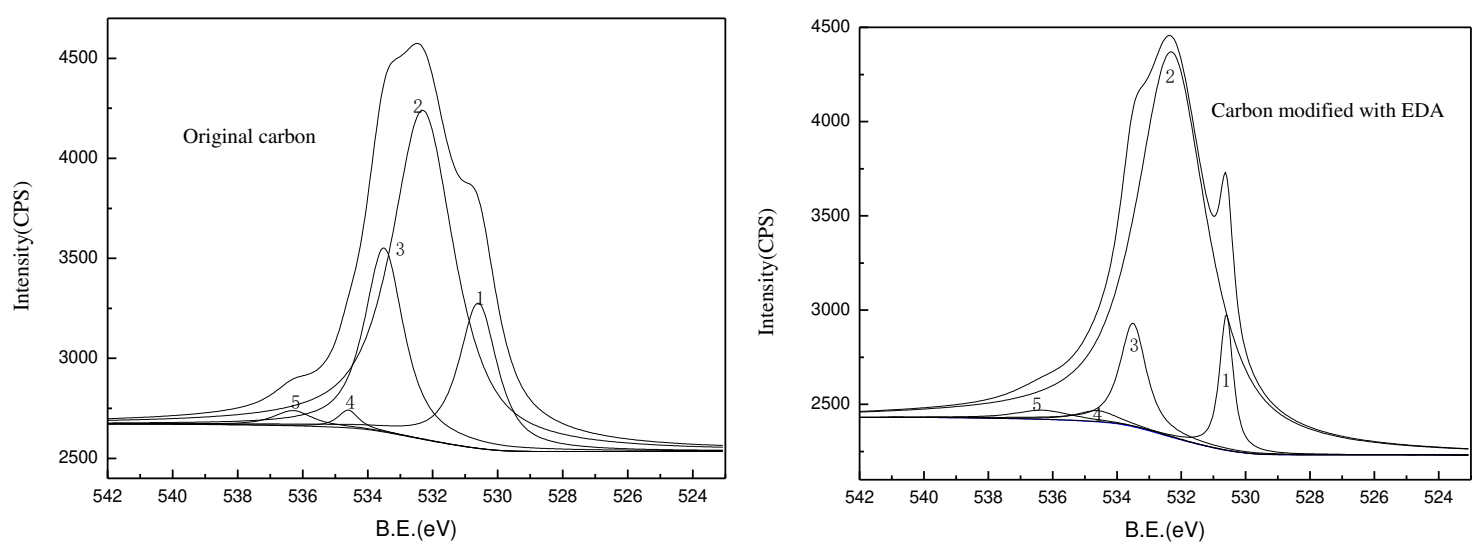

Fig. 501 s spectra of the original carbon and the modified carbon

The XPS O 1s spectra depicted in Fig. 8 are resolved into five individual component peaks. The molar percentages based on the peak resolution are listed in Table 2. The data illustrated in Table 2 reveals that $\mathrm{C}=\mathrm{O}$ bond in the carboxyl group decreases sharply from $16.80 \%$ to $5.64 \%$ after the EDA 
treatment. The molar percentage of $\mathrm{C}=\mathrm{O}$ bond in amide groups on the carbon modified is $23.08 \%$ above that on the original one. The oxygen in ether group decreases from $21.07 \%$ to $8.31 \%$. The functional groups that peak 4 stands for on B1 are $1.41 \%$ while those on AC are only $1.06 \%$. In terms of XPS data, it can be concluded that acidic groups, such as carboxyl, carbonyl and lactonic group decrease sharply due to the EDA treatment. The amide groups increases obviously.

Table 2 Fitted O1s peak parameters deduced from XPS for carbon samples

\begin{tabular}{ccccc}
\hline Peaks & $\begin{array}{c}\text { B.E } \\
(\mathrm{eV})\end{array}$ & Assignment & Original carbon & Carbon modified \\
& & & $(\%)$ & $(\%)$ \\
\hline 1 & 530.6 & $\mathrm{C}=\mathrm{O}$ (Carboxyl) & 16.80 & 5.64 \\
2 & 532.3 & $\mathrm{C}=\mathrm{O}($ ester, amides $)$ & 59.96 & 83.04 \\
3 & 533.5 & $\mathrm{C}-\mathrm{O}-\mathrm{C}($ ether oxygen $)$ & 21.07 & 8.31 \\
4 & 534.6 & $\mathrm{C}-\mathrm{OH},-\mathrm{COOH}, \mathrm{N}-\mathrm{O}-\mathrm{C}$ & 1.06 & 1.41 \\
5 & 536.3 & $\mathrm{H}_{2} \mathrm{O}_{\text {ads }}, \mathrm{O}_{2 \text { ads }}$ & 1.71 & 1.60 \\
\hline
\end{tabular}

The concentrations of the surface functional groups determined by Boehm titration listed in Table 3 may also account for the improvement of the carbon catalytic ability. It can be seen that the total acidic groups and basic groups have been changed greatly after being modified with EDA solution. The total basic groups on the modified carbon are significantly raised while the total acidic groups are reduced compared to those on the original one. For instance, the total basic groups on the original carbon are only $4.02 \times 10^{-4} \mathrm{~mol} \mathrm{~g}^{-1}$ but those on the one immersed in $6.0 \mathrm{~mol} \mathrm{~L}-1$ EDA solution rise to $7.18 \times 10^{-4} \mathrm{~mol} \mathrm{~g}^{-1}$. The phenolic hydroxyl on this modified carbon is reduced by $81.25 \%$ compared with that on the unmodified one. The carboxylic also drops greatly from $1.50 \times 10^{-4} \mathrm{~mol} \mathrm{~g}^{-1}$ to $0.11 \times 10^{-4} \mathrm{~mol} \mathrm{~g}^{-1}$. And the amount of lactonic on this modified carbon is nearly one half times that on the original one. The physical characteristics of the carbon samples listed in Table 4 suggest that the modification with EDA solution gives rise to the increase in total surface area, mesopore area and micropore area on the carbon surface. For instance, the total surface area on the original carbon is $779 \mathrm{~m}^{2} \mathrm{~g}^{-1}$, but that on the one impregnated in $5.0 \mathrm{~mol} \mathrm{~L}^{-1}$ EDA solution is $813 \mathrm{~m}^{2} \mathrm{~g}^{-1}$. The micropore area on this modified carbon increases by $26 \mathrm{~m}^{2}$ $\mathrm{g}^{-1}$ compared with that on the original one. The reason for the magnification of both $\mathrm{S}_{\mathrm{BET}}$ and $\mathrm{S}_{\text {mic }}$ is that ethylenediamine can etch the activated carbon and remove the ash in the pores. Furthermore, ethylenediamine as well as the acidic groups on the carbon surface decompose at high temperature, which may bring about an increase in the pore structure and surface area on the carbon surface. The modification with EDA solution not only increases the basic functional groups on the carbon surface but also amplifies the pore structure of the carbon, which helps to adsorb Fe(III)NTA and disintegrate it into $\mathrm{Fe}^{3+}$ and $\mathrm{NTA}^{3-}$, accelerating the reduction of $\mathrm{Fe}(\mathrm{III})$. Therefore, the carbon modified with EDA is superior to the original one as a catalyst in the regeneration of Fe(III)NTA. 
Table 3 also manifests that the total basic groups goes up gradually while the total acid groups go down slightly as the EDA concentration increases from $3.0 \mathrm{~mol} \mathrm{~L}^{-1}$ to $6.0 \mathrm{~mol} \mathrm{~L}^{-1}$. This may be because more ethylenediamine is adsorbed onto the activated carbon and reacts with the acidic groups on the carbon surface as EDA concentration increases, which is beneficial to the formation of basic groups at high temperature.

Table 3 Chemical characteristic of carbon samples (EDA concentration)

\begin{tabular}{ccccccc}
\hline $\begin{array}{c}\text { EDA } \\
\text { concentration }\end{array}$ & $\begin{array}{c}\text { Phenolic hydroxyl } \\
10^{-4} \mathrm{~mol} \mathrm{~g}^{-1}\end{array}$ & $\begin{array}{c}\text { Carboxylic } \\
10^{-4} \mathrm{~mol} \mathrm{~g}^{-1}\end{array}$ & $\begin{array}{c}\text { Lactonic } \\
10^{-4} \mathrm{~mol} \mathrm{~g}^{-1}\end{array}$ & $\begin{array}{c}\text { Total acid } \\
10^{-4} \mathrm{~mol} \mathrm{~g}^{-1}\end{array}$ & $\begin{array}{c}\text { Total basic } \\
10^{-4} \mathrm{~mol} \mathrm{~g}^{-1}\end{array}$ & $\begin{array}{c}\mathbf{p H}_{\mathbf{p z c}} \\
0 \mathrm{~mol} \mathrm{~L}^{-1}\end{array}$ \\
1.28 & 1.50 & 0.45 & 3.23 & 4.02 & 8.12 \\
$3.0 \mathrm{~mol} \mathrm{~L}^{-1}$ & 0.25 & 0.12 & 0.35 & 0.72 & 6.95 & 10.25 \\
$5.0 \mathrm{~mol} \mathrm{~L}^{-1}$ & 0.25 & 0.11 & 0.24 & 0.60 & 7.09 & 10.60 \\
$6.0 \mathrm{~mol} \mathrm{~L}^{-1}$ & 0.24 & 0.11 & 0.24 & 0.59 & 7.18 & 10.69
\end{tabular}

The data in Table 4 reveals that the total surface area and micropore area magnify by $10 \mathrm{~m}^{2} / \mathrm{g}$ and 17

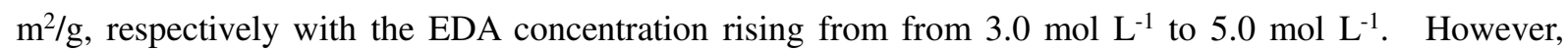
when the EDA concentration increases from $5.0 \mathrm{~mol} \mathrm{~L}^{-1}$ to $6.0 \mathrm{~mol} \mathrm{~L}^{-1}$, the total surface area and micropore area decrease by $8 \mathrm{~m}^{2} / \mathrm{g}$ and $10 \mathrm{~m}^{2} / \mathrm{g}$, respectively. Therefore, the $\mathrm{S}_{\mathrm{BET}}$ of the carbon will increase with the EDA concentration because more pores will be produced due to the reaction bwtween EDA and carbon when the samples are calcined at high temperature. However, as the EDA concentration increases over 5 mol L-1, $\mathrm{S}_{\mathrm{BET}}$ decreases because some micropores will be transformed into mesopores and macropores due to the violent reaction between carbon and EDA.

Table 4 Physical characteristics of carbon samples (EDA concentration)

\begin{tabular}{ccccccc}
\hline $\begin{array}{c}\text { EDA concentration } \\
/(\mathrm{mol} / \mathrm{L})\end{array}$ & $\begin{array}{c}\mathbf{S}_{\text {BET }} \\
\left(\mathrm{m}^{2} / \mathrm{g}\right)\end{array}$ & $\begin{array}{c}\mathbf{S}_{\text {mic }} \\
\left(\mathrm{m}^{2} / \mathrm{g}\right)\end{array}$ & $\begin{array}{c}\mathbf{S}_{\text {ext }} \\
\left(\mathrm{m}^{2} / \mathrm{g}\right)\end{array}$ & $\begin{array}{c}\mathbf{V}_{\mathbf{t}} \\
\left(\mathrm{m}^{3} / \mathrm{g}\right)\end{array}$ & $\begin{array}{c}\mathbf{V}_{\text {mic }} \\
\left(\mathrm{m}^{3} / \mathrm{g}\right)\end{array}$ & $\begin{array}{c}\mathbf{D}_{\text {BJH }} \\
(\mathrm{nm})\end{array}$ \\
\hline 0 & 779 & 679 & 100 & 0.376 & 0.061 & 2.143 \\
3.0 & 803 & 688 & 115 & 0.431 & 0.072 & 2.146 \\
5.0 & 813 & 705 & 108 & 0.440 & 0.070 & 2.142 \\
6.0 & 805 & 695 & 110 & 0.430 & 0.069 & 2.165
\end{tabular}

$\mathrm{S}_{\mathrm{BET}}$ and $\mathrm{S}_{\mathrm{mic}}$ of the carbon soaked in $5.0 \mathrm{~mol} \mathrm{~L}^{-1}$ EDA solution are bigger than those of the carbon soaked in $6.0 \mathrm{~mol} \mathrm{~L}^{-1} \mathrm{EDA}$ solution and the basicity of the former is slightly weaker than that of the latter. Greater $S_{\mathrm{BET}}$ and $\mathrm{S}_{\mathrm{mic}}$ are conducive to the catalytic ability of the carbon in the regeneration of Fe(II)NTA. Therefore, the carbon soaked in $5.0 \mathrm{~mol} \mathrm{~L}^{-1}$ EDA solution exhibits stronger catalytic ability than the carbon soaked in $6.0 \mathrm{~mol} \mathrm{~L}^{-1} \mathrm{EDA}$ solution. $\mathrm{S}_{\mathrm{BET}}$ of the carbon soaked in $6.0 \mathrm{~mol} \mathrm{~L}^{-1}$ EDA solution is slightly smaller than that of the carbon soaked in $3.0 \mathrm{~mol} \mathrm{~L}^{-1} \mathrm{EDA}$ solution. But the basicity of the carbon soaked in $6.0 \mathrm{~mol} \mathrm{~L}{ }^{-1} \mathrm{EDA}$ solution is much stronger than that of the one soaked in $3.0 \mathrm{~mol} \mathrm{~L}^{-1}$ EDA solution. At 
a $\mathrm{pH}$ below the isoelectric point of the carbon, the carbon is positively charged and will adsorb preferentially anionic species(Rodriduez-Reinoso 1998). The higher the $\mathrm{pH}_{\mathrm{pzc}}$, the greater the positive charge density on the carbon surface, which is favorable for the adsorbability of the anionic NTA and sulfite on activated carbon. Thus, the reduction of Fe(III)NTA is benefited. The basic groups on the carbon samples play a more important role than their physical structure. Therefore, the carbon soaked in $6.0 \mathrm{~mol} \mathrm{~L}^{-1}$ EDA solution gets a higher Fe(III)NTA conversion than the one immersed in $3.0 \mathrm{~mol} \mathrm{~L}^{-1} \mathrm{EDA}$ solution .

\subsection{Effect of impregnation time}

The duration of the carbon impregnated in EDA solution is a vital factor influencing the effect of carbon modification. $2 \mathrm{~g}$ activated carbon of 100-120 mesh were immersed in 5.0 mol L-1 EDA solution at room temperature for $4,6,8,10,12$ and $15 \mathrm{~h}$, respectively. Then the carbon samples were calcined at $800{ }^{\circ} \mathrm{C}$ for $4 \mathrm{~h}$ in $\mathrm{N}_{2}$. The Fe(III)NTA conversions catalyzed by these carbon samples are shown in Fig. 6. A conclusion can be drawn from Fig. 6 that the best impregnation time is $6 \mathrm{~h}$. After 90 min's reaction, the $\mathrm{Fe}(\mathrm{III})$ NTA conversions obtained by the carbon impregnated in EDA solution for 4, 6, 8, 10,12 and $15 \mathrm{~h}$ were increased by $3.47 \%, 9.17 \%, 7.24 \%, 6.66 \%, 2.31 \%$ and $1.54 \%$, respectively, compared with that of $41.07 \%$ obtained by the original carbon. The carbon soaked in EDA solution for $6 \mathrm{~h}$ exhibits the best catalytic activity.

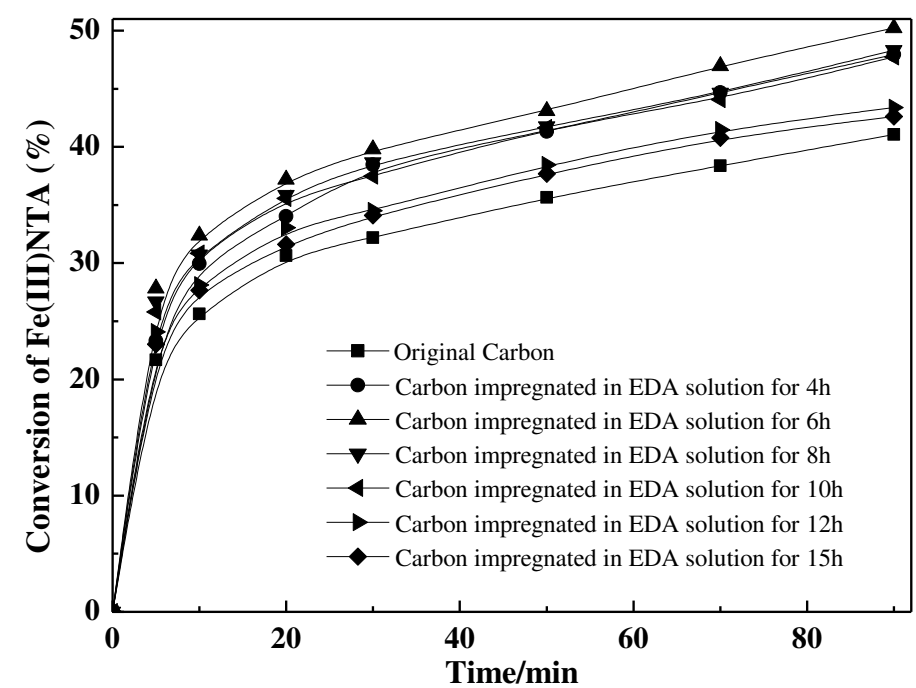

Fig. 6 Effect of impregnation time on the catalytic performance of activated carbon $[\mathrm{Fe}(\mathrm{III}) \mathrm{NTA}]=0.01 \mathrm{~mol} \mathrm{l}^{-1}, \mathrm{SO}_{3}{ }^{2-}=0.1 \mathrm{~mol} \mathrm{l}^{-1}, \mathrm{pH}=6.17,300 \mathrm{rpm}, 70^{\circ} \mathrm{C}$

The data in Table 5 reveals that the total acidic groups decrease from $0.80 \times 10^{-4} \mathrm{~mol} \mathrm{~g}^{-1}$ to $0.60 \times 10^{-4}$ mol $\mathrm{g}^{-1}$ as the impregnation time prolongs from $4 \mathrm{~h}$ to $6 \mathrm{~h}$. But if the impregnation time extends to $8 \mathrm{~h}$, the amount of acidic functional groups is almost unchanged. The total basic groups increase with the impregnation time because the reaction between carbon and EDA is of benefit to the enhancement of the basicity of the carbon. The physical characteristics shown in Table 6 indicate that $\mathrm{S}_{\mathrm{BET}}$ decreases from $816 \mathrm{~m}^{2} \mathrm{~g}^{-1}$ to $705 \mathrm{~m}^{2} \mathrm{~g}^{-1}$ with the extension of the impregnation time from $4 \mathrm{~h}$ to $8 \mathrm{~h}$.. This may be 
because the long reaction time between carbon and EDA turns some micropores into mesopores and macropores.

Though the carbon soaked in the EDA solution for $4 \mathrm{~h}$ has the biggest $\mathrm{S}_{\mathrm{BET}}$, it exhibits the weakest catalytic ability in the regeneration of $\mathrm{Fe}(\mathrm{II}) \mathrm{NTA}^{-}$because it holds the smallest basic groups on its surface. The basic groups on the carbon soaked in the EDA solution for $8 \mathrm{~h}$ are slightly more than those on the one immersed in the EDA solution for $6 \mathrm{~h}$ but the latter holds bigger $\mathrm{S}_{\mathrm{BET}}$ than the former. Therefore, the carbon soaked in the EDA solution for $6 \mathrm{~h}$ can obtain a higher Fe(III)NTA conversion than the one soaked in the EDA solution for $8 \mathrm{~h}$. Both the physical structure and surface chemistry of the activated carbon determine its catalytic ability in the reduction of Fe(III)NTA jointly.

Table 5 Chemical characteristic of carbon samples (Impregnation time)

\begin{tabular}{ccccccc}
\hline $\begin{array}{c}\text { Impregnation } \\
\text { time }\end{array}$ & $\begin{array}{c}\text { Phenolic hydroxyl } \\
10^{-4} \mathrm{~mol} / \mathrm{g}\end{array}$ & $\begin{array}{c}\text { Carboxylic } \\
10^{-4} \mathrm{~mol} / \mathrm{g}\end{array}$ & $\begin{array}{c}\text { Lactonic } \\
10^{-4} \mathrm{~mol} / \mathrm{g}\end{array}$ & $\begin{array}{c}\text { Total acid } \\
10^{-4} \mathrm{~mol} / \mathrm{g}\end{array}$ & $\begin{array}{r}\text { Total basic } \\
10^{-4} \mathrm{~mol} / \mathrm{g}\end{array}$ & $\mathbf{p H}_{\mathbf{p z c}}$ \\
\hline $4 \mathrm{~h}$ & 0.28 & 0.15 & 0.37 & 0.80 & 7.03 & 10.40 \\
$6 \mathrm{~h}$ & 0.25 & 0.11 & 0.24 & 0.60 & 7.09 & 10.60 \\
$8 \mathrm{~h}$ & 0.23 & 0.13 & 0.26 & 0.62 & 7.13 & 10.69 \\
\hline
\end{tabular}

Table 6 Physical characteristics of carbon samples (Impregnation time)

\begin{tabular}{ccccccc}
\hline $\begin{array}{c}\text { Impregnation } \\
\text { time }\end{array}$ & $\begin{array}{c}\mathbf{S}_{\text {BET }} \\
\mathrm{m}^{2} / \mathrm{g}\end{array}$ & $\begin{array}{c}\mathbf{S}_{\text {mic }} \\
\mathrm{m}^{2} / \mathrm{g}\end{array}$ & $\begin{array}{c}\mathbf{S}_{\text {ext }} \\
\mathrm{m}^{2} / \mathrm{g}\end{array}$ & $\begin{array}{c}\mathbf{V}_{\mathbf{t}} \\
\mathrm{m}^{3} / \mathrm{g}\end{array}$ & $\begin{array}{c}\mathbf{V}_{\text {mic }} \\
\mathrm{m}^{3} / \mathrm{g}\end{array}$ & $\begin{array}{c}\mathbf{D}_{\mathbf{B J H}} \\
\mathrm{nm}\end{array}$ \\
\hline $\mathbf{4} \mathbf{h}$ & 816 & 703 & 113 & 0.438 & 0.071 & 2.146 \\
$\mathbf{6} \mathbf{h}$ & 813 & 705 & 108 & 0.440 & 0.070 & 2.165 \\
$\mathbf{8} \mathbf{h}$ & 791 & 682 & 109 & 0.427 & 0.070 & 2.159 \\
\hline
\end{tabular}

\subsection{Effect of calcination temperature}

To explore the effect of calcination temperature on the catalytic capacity of the activated carbon, four carbon samples were heated in $\mathrm{N}_{2}$ for $4 \mathrm{~h}$ at $600,700,800$, and $850{ }^{\circ} \mathrm{C}$, respectively after having been impregnated in $5.0 \mathrm{~mol} \mathrm{~L}^{-1} \mathrm{EDA}$ solution for $6 \mathrm{~h}$ at ambient temperature. The prepared samples were used to catalyze the reduction of $\mathrm{Fe}(\mathrm{III}) \mathrm{NTA}$ at $70{ }^{\circ} \mathrm{C}$. The conversions of $\mathrm{Fe}(\mathrm{III}) \mathrm{NTA}$ presented in Fig. 7 prove that the best calcination temperature for the carbon modification is $700{ }^{\circ} \mathrm{C}$. After 90 min's reaction, the $\mathrm{Fe}$ (III)NTA conversion obtained increases from 51.01 to $53.62 \%$ as the calcination temperature is raised from 600 to $700{ }^{\circ} \mathrm{C}$. However, when the temperature rises further to $800{ }^{\circ} \mathrm{C}$, the $\mathrm{Fe}(\mathrm{III}) \mathrm{NTA}$ conversion drops to $50.24 \%$. 


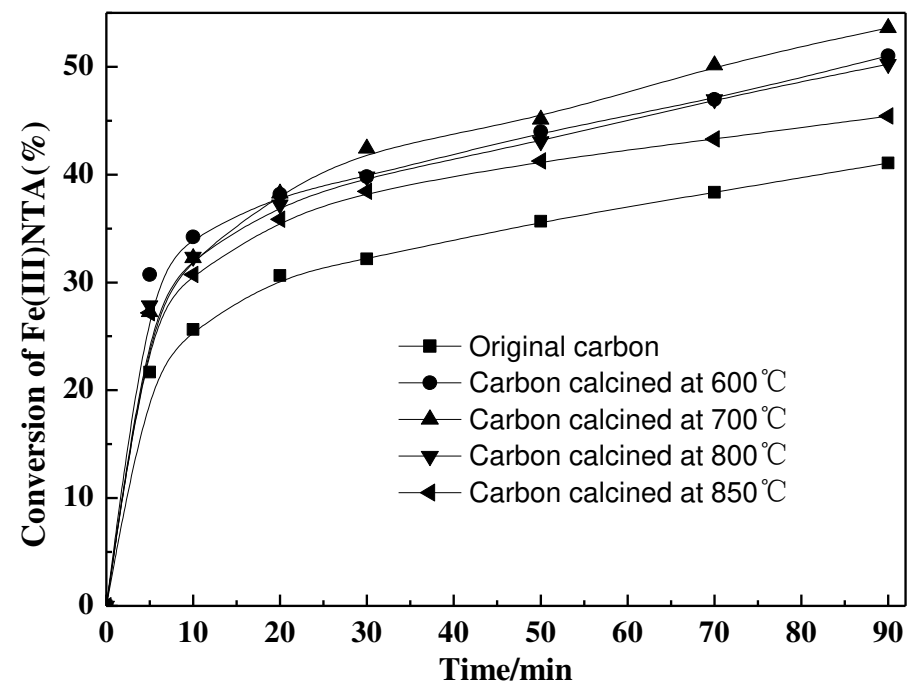

Fig. 7 Effect of calcination temperature on the catalytic performance of activated carbon

$[\mathrm{Fe}(\mathrm{IIII}) \mathrm{NTA}]=0.01 \mathrm{~mol} \mathrm{l}^{-1}, \mathrm{SO}_{3}{ }^{2-}=0.1 \mathrm{~mol} \mathrm{l}^{-1}, \mathrm{pH}=6.17,300 \mathrm{rpm}, 70^{\circ} \mathrm{C}$

Table 7 presents the chemical functional groups of the carbon samples impregnated in $5.0 \mathrm{~mol} \mathrm{~L}^{-1}$ EDA solution for $6 \mathrm{~h}$ followed by being carbonized for $4 \mathrm{~h}$ at 600,700 , and $800{ }^{\circ} \mathrm{C}$, respectively. It can be seen that the total acidic groups and the total basic groups are almost unchanged when calcinating the carbon samples at 600 and $700{ }^{\circ} \mathrm{C}$. The total basic groups decrease from $7.20 \times 10^{-4} \mathrm{~mol} \mathrm{~g}^{-1}$ to $7.01 \times 10^{-4}$ mol g${ }^{-1}$ when the calcining temperature rises to $800{ }^{\circ} \mathrm{C}$. This may be because the acidic functional groups on the carbon surface such as carboxyl, lactone and phenolic hydroxyl have been decomposed sufficiently above $600{ }^{\circ} \mathrm{C}$ and if the calcination temperature increases to $800{ }^{\circ} \mathrm{C}$, some basic functional groups begin to decompose. The physical characteristics illustrated in Table 8 exhibit that the total surface area, mesopore area and micropore area of the carbon samples increase gradually with the calcination temperature rising from 600 to $800{ }^{\circ} \mathrm{C}$ because more micropores and mesopores are produced due to the reaction between EDA and carbon proceeding more violently at higher temperature.

In spite of its biggest $\mathrm{S}_{\mathrm{BET}}$, the carbon calcined at $800{ }^{\circ} \mathrm{C}$ gets the lowest $\mathrm{Fe}$ (III)NTA conversion because it holds less basic groups than the other two samples. The carbon calcined at $700{ }^{\circ} \mathrm{C}$ holds similar chemistry characteristics with the carbon calcined at $600{ }^{\circ} \mathrm{C}$, the former is superior to the latter as a catalyst in the regeneration of $\mathrm{Fe}(\mathrm{II}) \mathrm{NTA}^{-}$because the former owns larger surface area.

Table 7 Chemical characteristics of carbon samples (calcination temperature)

\begin{tabular}{|c|c|c|c|c|c|c|}
\hline $\begin{array}{l}\text { Activation } \\
\text { temperature }\end{array}$ & $\begin{array}{c}\text { Phenolic hydroxyl } \\
10^{-4} \mathrm{~mol} \mathrm{~g}^{-1}\end{array}$ & $\begin{array}{l}\text { Carboxylic } \\
10^{-4} \mathrm{~mol} \mathrm{~g}^{-1}\end{array}$ & $\begin{array}{c}\text { Lactonic } \\
10^{-4} \mathrm{~mol} \mathrm{~g}^{-1}\end{array}$ & $\begin{array}{c}\text { Total acid } \\
10^{-4} \mathrm{~mol} \mathrm{~g}^{-1}\end{array}$ & $\begin{array}{l}\text { Total basic } \\
10^{-4} \mathrm{~mol} \mathrm{~g}^{-1}\end{array}$ & $\mathbf{p H}_{\mathbf{p z c}}$ \\
\hline $600^{\circ} \mathrm{C}$ & 0.25 & 0.12 & 0.23 & 0.6 & 7.20 & 10.83 \\
\hline $700^{\circ} \mathrm{C}$ & 0.22 & 0.11 & 0.25 & 0.58 & 7.20 & 10.78 \\
\hline $800^{\circ} \mathrm{C}$ & 0.25 & 0.11 & 0.24 & & 7.01 & 10.60 \\
\hline
\end{tabular}


0.60

\begin{tabular}{ccccccc}
\multicolumn{7}{c}{ Table 8 Physical characteristics of carbon samples (calcination temperature) } \\
\hline $\begin{array}{c}\text { Activation } \\
\text { temperature }\end{array}$ & $\begin{array}{c}\mathbf{S}_{\mathrm{BET}} \\
\mathrm{m}^{2} / \mathrm{g} \mathrm{g}^{-1}\end{array}$ & $\begin{array}{c}\mathbf{S}_{\text {mic }} \\
\mathrm{m}^{2} \mathrm{~g}^{-1}\end{array}$ & $\begin{array}{c}\mathbf{S}_{\text {ext }} \\
\mathrm{m}^{2} \mathrm{~g}^{-1}\end{array}$ & $\begin{array}{c}\mathbf{V}_{\mathbf{t}} \\
\mathrm{m}^{3} \mathrm{~g}^{-1}\end{array}$ & $\begin{array}{c}\mathbf{V}_{\text {mic }} \\
\mathrm{m}^{3} \mathrm{~g}^{-1}\end{array}$ & $\begin{array}{c}\mathbf{D}_{\text {BJH }} \\
\mathrm{nm}\end{array}$ \\
\hline $600^{\circ} \mathrm{C}$ & 789 & 696 & 93 & 0.426 & 0.064 & 2.157 \\
$700^{\circ} \mathrm{C}$ & 800 & 702 & 98 & 0.417 & 0.067 & 2.149 \\
$800^{\circ} \mathrm{C}$ & 813 & 705 & 108 & 0.440 & 0.070 & 2.165
\end{tabular}

\subsection{Effect of calcination time}

The effect of calcination time on the catalytic capability of activated carbon should also be investigated. Three carbon samples were calcined in $\mathrm{N}_{2}$ at $700{ }^{\circ} \mathrm{C}$ for 3,4 , and $5 \mathrm{~h}$, respectively after being immersed in $5.0 \mathrm{~mol} \mathrm{~L}{ }^{-1}$ EDA solution for $6 \mathrm{~h}$ at ambient temperature. Then the obtained samples were used to speed up the reduction of Fe(III)NTA at $70{ }^{\circ} \mathrm{C}$. The conversions of Fe(III)NTA presented in Fig. 8 reveals that the optimal calcination time for the carbon modification is $4 \mathrm{~h}$. After 90 min's operation, the $\mathrm{Fe}(\mathrm{III}) \mathrm{NTA}$ conversion catalyzed by the carbon carbonized for $4 \mathrm{~h}$ is $53.62 \%$ while those catalyzed by the samples carbonized for 3 and $5 \mathrm{~h}$ are 48.79 and $52.84 \%$, respectively.

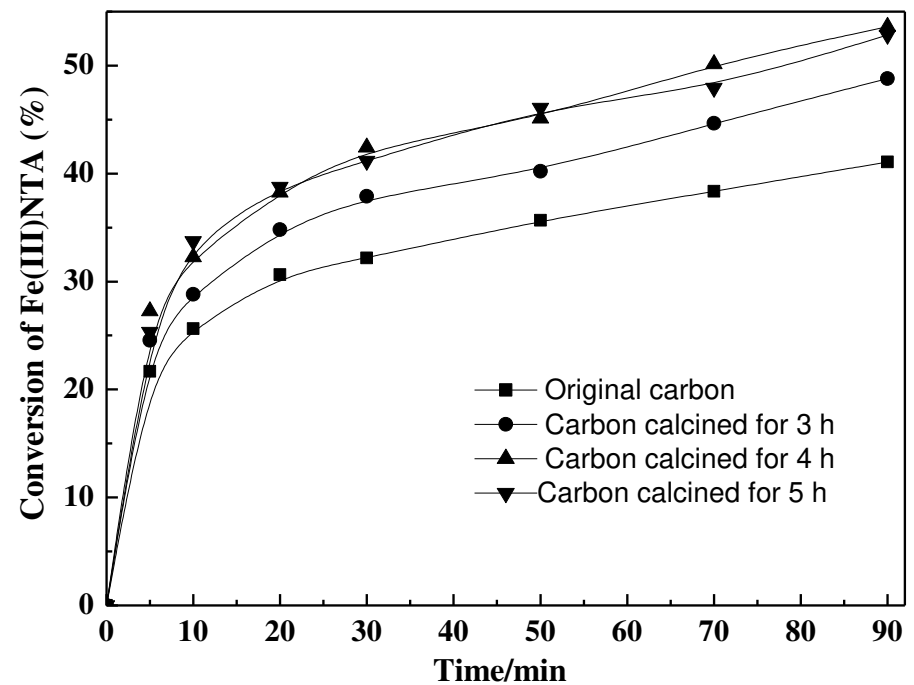

Fig. 8 Effect of calcination time on the catalytic performance of activated carbon

$$
[\mathrm{Fe}(\mathrm{III}) \mathrm{NTA}]=0.01 \mathrm{~mol} \mathrm{l}^{-1}, \mathrm{SO}_{3}{ }^{2-}=0.1 \mathrm{~mol} \mathrm{l}^{-1}, \mathrm{pH}=6.17,300 \mathrm{rpm}, 70^{\circ} \mathrm{C}
$$

The data listed in Table 9 depicts that the total acidic groups and the total basic groups on the surface of activated carbon change little as the calcination time prolongs from $3 \mathrm{~h}$ to $5 \mathrm{~h}$. But the physical characteristics shown in Table 10 indicates that when the calcination time is extended from $3 \mathrm{~h}$ to $4 \mathrm{~h}$, the total surface area and micropore area increase from $782 \mathrm{~m}^{2} \mathrm{~g}^{-1}$ and $674 \mathrm{~m}^{2} \mathrm{~g}^{-1}$ to $800 \mathrm{~m}^{2} \mathrm{~g}^{-1}$ and $702 \mathrm{~m}^{2} \mathrm{~g}^{-1}$, respectively. This is because appropriate extension of the calcination duration is favorable for the formation of micropores resulted from the reaction between carbon and EDA. The total surface area decreases to $791 \mathrm{~m}^{2} \mathrm{~g}^{-1}$ if the calcination time prolongs further to $5 \mathrm{~h}$. The reason may be that excessive 
calcination time leads to the transformation of some mesopores to macropores. The Fe(III)NTA conversions they have got are in accordance with the sequence of their physical structures. Therefore, the best calcination time is selected to be $4 \mathrm{~h}$.

Table 9 Chemical characteristics of carbon samples (calcination time)

\begin{tabular}{ccccccc}
\hline $\begin{array}{c}\text { Activation } \\
\text { time }\end{array}$ & $\begin{array}{c}\text { Phenolic hydroxyl } \\
10^{-4} \mathrm{~mol} / \mathrm{g}\end{array}$ & $\begin{array}{c}\text { Carboxylic } \\
10^{-4} \mathrm{~mol} / \mathrm{g}\end{array}$ & $\begin{array}{c}\text { Lactonic } \\
10^{-4} \mathrm{~mol} / \mathrm{g}\end{array}$ & $\begin{array}{c}\text { Total acid } \\
10^{-4} \mathrm{~mol} / \mathrm{g}\end{array}$ & $\begin{array}{c}\text { Total basic } \\
10^{-4} \mathrm{~mol} / \mathrm{g}\end{array}$ & $\mathbf{p H}_{\mathbf{p z c}}$ \\
\hline $\mathbf{3 h}$ & 0.27 & 0.10 & 0.22 & 0.59 & 7.21 & 10.80 \\
$\mathbf{4} \mathbf{h}$ & 0.22 & 0.11 & 0.25 & 0.58 & 7.20 & 10.78 \\
$\mathbf{5} \mathbf{h}$ & 0.21 & 0.11 & 0.25 & 0.57 & 7.18 & 10.69 \\
\hline
\end{tabular}

Table 10 Physical characteristics of carbon samples (calcination time)

\begin{tabular}{ccccccc}
\hline $\begin{array}{c}\text { Activation } \\
\text { time }\end{array}$ & $\begin{array}{c}\mathbf{S}_{\text {BET }} \\
\left(\mathrm{m}^{2} / \mathrm{g}\right)\end{array}$ & $\begin{array}{c}\mathbf{S}_{\text {mic }} \\
\left(\mathrm{m}^{2} / \mathrm{g}\right)\end{array}$ & $\begin{array}{c}\mathbf{S}_{\text {ext }} \\
\left(\mathrm{m}^{2} / \mathrm{g}\right)\end{array}$ & $\begin{array}{c}\mathbf{V}_{\mathbf{t}} \\
\left(\mathrm{m}^{3} / \mathrm{g}\right)\end{array}$ & $\begin{array}{c}\mathbf{V}_{\text {mic }} \\
\left(\mathrm{m}^{3} / \mathrm{g}\right)\end{array}$ & $\begin{array}{c}\text { D }_{\text {BJH }} \\
(\mathrm{nm})\end{array}$ \\
\hline $3 \mathrm{~h}$ & 782 & 674 & 108 & 0.422 & 0.072 & 2.157 \\
$4 \mathrm{~h}$ & 800 & 702 & 98 & 0.417 & 0.067 & 2.149 \\
$5 \mathrm{~h}$ & 791 & 704 & 87 & 0.426 & 0.060 & 2.154 \\
\hline
\end{tabular}

\section{Simultaneous removal of $\mathrm{NO}$ and $\mathrm{SO}_{2}$}

The experimental schematic apparatus of the simultaneous removal of $\mathrm{NO}$ and $\mathrm{SO}_{2}$ with $\mathrm{Fe}(\mathrm{II}) \mathrm{NTA}^{-}$ solution as well as the $\mathrm{Fe}(\mathrm{II}) \mathrm{NTA}^{-}$regeneration catalyzed by the raw carbon and the modified carbon is shown in Fig. 1. The modified carbon was treated with EDA solution under the optimal condition discussed previously. In the experiment, both of the absorber and the regeneration reactor are controlled at $50^{\circ} \mathrm{C}$. The absorption solution is a mixture of $500 \mathrm{~mL}^{\circ} .05 \mathrm{~mol} \mathrm{~L}^{-1} \mathrm{Fe}(\mathrm{II}) \mathrm{NTA}^{-}$and $0.04 \mathrm{~mol} \mathrm{~L}^{-1}$ $\mathrm{Na}_{2} \mathrm{SO}_{3}$. The concentrations of $\mathrm{SO}_{2}$ and $\mathrm{NO}$ in the gas inlet are $1800 \mathrm{ppm}$ and $580 \mathrm{ppm}$, respectively. $\mathrm{O}_{2}$ in the simulated flue gas is $5.0 \%$ (volume). The gas flow rate is $270 \mathrm{ml} \mathrm{min}^{-1}$ and that of the scrubbing solution is controlled by a peristaltic pump at $25 \mathrm{ml} \mathrm{min}^{-1}$. The $\mathrm{pH}$ value of the solution in the circulation tank is controlled around 5.5. The experimental results are shown in Fig. 9.

It can be seen from Fig. 9 that the removal efficiency of NO decreases from $100 \%$ to about $35.9 \%$ after $2.4 \mathrm{~h}$ run due to the consumption of $\mathrm{Fe}(\mathrm{II}) \mathrm{NTA}^{-}$. At this time, the Fe(II)NTA- regeneration is started. Obviously, the NO removal efficiency regain quickly in these two operations after the regeneration process begins. But there is evident difference between two operations. The NO removal efficiency rises to about $81.3 \%$ in $1 \mathrm{~h}$ and then begins to decrease gradually under the catalysis of the unmodified carbon. After $58 \mathrm{~h}$ operation, the NO removal efficiency drops to $57.9 \%$ and is maintained at $52.1-54.4 \%$. As a contrast, when Fe(II)NTA- regeneration is catalyzed by the modified carbon, the NO removal efficiency 
reaches to $100 \%$ in about $15 \mathrm{~min}$ and is maintained at $100 \%$ for $1.2 \mathrm{~h}$. Thirty hours later, the NO removal efficiency decreases to $78.4 \%$ and fluctuates between $73.7 \%$ and $77.3 \%$ in the run. Besides, there is no $\mathrm{SO}_{2}$ detected in the outlet gas by FTIR in the whole process. The explanation for such phenomenon is as follows. Fe(II)NTA- is gradually oxidized to Fe(III)NTA by oxygen, leading to the reduction in NO removal efficiency. After the $\mathrm{Fe}(\mathrm{II}) \mathrm{NTA}^{-}$regeneration starts, Fe(III)NTA is reduced by sulfite/bisulfite to $\mathrm{Fe}(\mathrm{II}) \mathrm{NTA}^{-}$under the catalysis of activated carbon and $\mathrm{Fe}(\mathrm{II}) \mathrm{NTA}(\mathrm{NO})^{-}$also reacts with sulfite/bisulfite to form $\mathrm{Fe}(\mathrm{II}) \mathrm{NTA}$ and $\mathrm{N}_{2}$. As the operation goes on, the sulfite consumed is balanced with the supplementary sulfite/bisulfite by $\mathrm{SO}_{2}$ dissolving into the scrubbing liquor. Therefore, the NO removal efficiency remains constant during the whole experiment. The experiments indicate that the modified activated carbon can gain a higher NO removal efficiency than the original activated carbon. As a consequence, the carbon modification with EDA solution is a cogent measures to ameliorate its catalytic capability in the simultaneous elimination of $\mathrm{NO}$ and $\mathrm{SO}_{2}$ with $\mathrm{Fe}(\mathrm{II}) \mathrm{NTA}^{-}$solution.

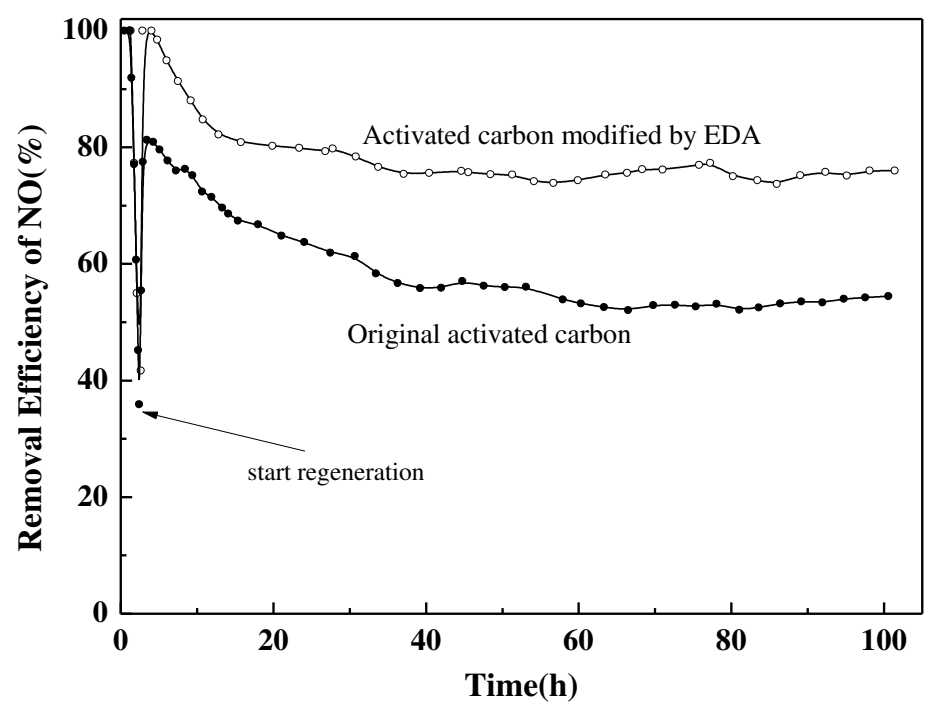

Fig. 8 NO removal coupled with Fe(II)NTA- regeneration catalyzed by activated carbon

\section{Conclusions}

Ethylenediamine solution has been used to modify activated carbon, and the following conclusions are obtained from the experiments:

(1) The catalytic capability of the activated carbon in the regeneration of $\mathrm{Fe}(\mathrm{II}) \mathrm{NTA}^{-}$is ameliorated conspicuously by treating the carbon with EDA solution. The best modification conditions are impregnating carbon in $5.0 \mathrm{~mol} \mathrm{~L}{ }^{-1}$ EDA solution for $6 \mathrm{~h}$ followed by carbonizing the sample at $700{ }^{\circ} \mathrm{C}$ for $4 \mathrm{~h}$ in $\mathrm{N}_{2}$.

(2) The carbon surface characterization demonstrates that the treatment with EDA solution gives rise to an 
evident increase in the basic groups and obvious decrease in acidic groups on the carbon surface. The BET results prove that the modification also brings about a slight increase in the surface area. And these changes are favorable for the improvement of the catalytic activity of the activated carbon in the generation of Fe(II)NTA ${ }^{-}$The catalytic ability of activated carbon in the Fe(II)NTA ${ }^{-}$generation relies on its physical structure and surface chemistry. The surface chemistry plays more important role than its physical structure in determining the catalytic capability of carbon.

(3) The modified coconut activated carbon can achieve a much higher NO removal efficiency than the unmodified coconut activated carbon. Therefore, this modification with EDA solution is an effective way to enhance the catalytic ability of the activated carbon in the simultaneous removal of $\mathrm{NO}$ and $\mathrm{SO}_{2}$ with Fe(II)NTA` solution.

\section{References}

Allwar A(2012) Characteristics of pore structures and surface chemistry of activated carbons by physisorption, Ftir and Boehm methods. IOSR J Applied Chem 2(1): 9-15.

Boehm HP(1994) Some aspects of the surface chemistry of carbon blacks and other carbons. Carbon 32(5): 759-769.

Chandrashekhar B, Pai P, Morone A, Sahu N, Pandey RA(2013) Reduction of $\mathrm{NO}_{\mathrm{x}}$ in Fe-EDTA and Fe-NTA solutions by an enriched bacterial population. Bioresource technology 130: 644-651.

Chandrashekhar B, Sahu N, Tabassum H, Pai P, Morone A, Pandey RA(2015) Treatment of ferrous-NTA-based $\mathrm{NO}_{\mathrm{x}}$ scrubber solution by an up-flow anaerobic packed bed bioreactor. Applied microbiology and biotechnology 99(12): 5281-5293.

Chen CJ, Li X, Tong ZF, Li Y, Li MF(2014) Modification process optimization, characterization and adsorption property of granular fir-based activated carbon. Applied Surf Sci 315: 203-211.

Chen P, Gu MY, Chen G, Liu, FS, Lin YY(2019) DFT study on the reaction mechanism of $\mathrm{N}_{2} \mathrm{O}$ reduction with CO catalyzed by char. Fuel 254: 115666.

Dou BL, Pan WG, Jin Q, Wang WH, Li Y(2009) Prediction of $\mathrm{SO}_{2}$ removal efficiency for wet Flue Gas Desulfurization. Energy Conversion \& Management 50(10):2547-2553.

Fu RQ, Liu Y, Lou ZM, Wang ZX, Baig SA, Xu XH (2016) Adsorptive removal of Pb (II) by magnetic activated carbon incorporated with amino groups from aqueous solutions. Journal of the Taiwan Institute of Chemical Engineers 62: 247-258.

Fu XF, Yang HP, Sun HH, Lu GH, Wu JM(2016) The multiple roles of ethylenediamine modification at $\mathrm{TiO}_{2} /$ activated carbon in determining adsorption and visible-light-driven photoreduction of aqueous $\mathrm{Cr}(\mathrm{VI})$. J Alloys and Compounds 662: 165-172.

Guo LN, Han CY, Zhang SL, Zhong Q, Ding J, Zhang BQ, Zeng YQ(2018) Enhancement effects of $\cdot \mathrm{O}_{2}{ }^{-}$ and $\cdot \mathrm{OH}$ radicals on $\mathrm{NO}_{x}$ removal in the presence of $\mathrm{SO}_{2}$ by using an $\mathrm{O}_{3} / \mathrm{H}_{2} \mathrm{O}_{2}$ AOP system with inadequate $\mathrm{O}_{3}\left(\mathrm{O}_{3} / \mathrm{NO}\right.$ molar ratio= 0.5$)$. Fuel 233: 769-777. 
Hofele J, van Velzen D, Langenkamp H, Schaber K(1996) Absorption of NO in aqueous solutions of FeIINTA: determination of the equilibrium constant. Chem Eng and Processing: Process Intensification 35(4): 295-300.

Kang MS, Shin J, Tae UY, Hwang J(2020) Simultaneous removal of gaseous $\mathrm{NO}_{\mathrm{x}}$ and $\mathrm{SO}_{2}$ by gas-phase oxidation with ozone and wet scrubbing with sodium hydroxide. Chem Eng J 381: 122601.

Khan NE, Adewuyi YG(2010) Absorption and Oxidation of Nitric Oxide (NO) by Aqueous Solutions of Sodium Persulfate in a Bubble Column Reactor. Ind Eng Chem Res 49: 8749-8760.

Liémans I, Thomas D(2013) Simultaneous NOx and SOx reduction from oxyfuel exhaust gases using acidic solutions containing hydrogen peroxide. Energy Procedia 37:1348-1356.

Li ZH, Chang XJ, Zou XJ, Zhu XB, Nie R, Hu Z, Li RJ (2009) Chemically-modified activated carbon with ethylenediamine for selective solid-phase extraction and preconcentration of metal ions. Analytica Chimica Acta 632: 272-277.

Ma SC, Chai J, Jiao KL, Ma L, Zhu SJ, Wu K(2017) Environmental influence and countermeasures for high humidity flue gas discharging from power plants. Renewable \& Sustainable Energy Reviews 73:225-235.

Messele A, Soares OSG.P, Órfão JJM, Stüber F, Bengoa C, Fortuny A, Fabregat A, Font J(2014) Zero-valent iron supported on nitrogen-containing activated carbon for catalytic wet peroxide oxidation of phenols. Appl. Catal. B: Environ. 154-155: 329-338.

Mondal MK, Chelluboyana VR(2013) New experimental results of combined $\mathrm{SO}_{2}$ and NO removal from simulated gas stream by $\mathrm{NaClO}$ as low-cost absorbent. Chem Eng J 217: 48-53.

O'reilly JM, Mosher RA(1983) Functional groups in carbon black by FTIR spectroscopy. Carbon 21(1): 47-51.

Pan W, Zhang X, Guo R, Zhou Y, Jin Q, Ren J(2015) A thermodynamic study of simultaneous removal of $\mathrm{SO}_{2}$ and $\mathrm{NO}$ by a $\mathrm{KMnO}_{4} /$ ammonia solution. Energy Sources, Part A: Recovery, Utilization, and Environmental Effects 37(7): 721-726.

Ravishankara AR, Daniel JS, Portmann RW(2009) Nitrous oxide $\left(\mathrm{N}_{2} \mathrm{O}\right)$ : the dominant ozone-depleting substance emitted in the 21st century. Science 326(5949): 123-125.

Rodriduez-Reinoso F(1998) The role of carbon materials in heterogeneous catalysis. Carbon 36(3): 159 -175 .

Saikawa E, Kim H, Zhong M, Avramov A, Zhao Y, Janssens-Maenhout G, Kurokawa J, Klimont Z, Wagner F, Naik V(2017) Comparison of emissions inventories of anthropogenic air pollutants and greenhouse gases in China. Atmospheric Chemistry \& Physics 17(10): 6393-6421.

Tang MH, Tu SP, Sun WZ(2020) Research progress of flue gas desulfurization and denitrification technology in coal-fired power plants. Scientific Journal of Intelligent Systems Research 2(10):71-79.

Toro RA, Donoso CS, Seguel RA, Morales RG.ES, Leiva MAG(2014) Photochemical ozone pollution in the Valparaiso Region, Chile. Air quality, atmosphere \& health: An international journal 7(1): 1-11.

Wang ZH, Liu, HJ, Fang ZW, Zhou, XZ, Long XL(2019) Production of isophthalic acid from M-Xylene catalyzed by Co(II) and HPW@C modified with $\mathrm{ZnCl}_{2}$ solution. Canadian Chem Eng 97(7): 2086-2096. 
Wolak M, van Eldik R(2002) To be or not to be NO in coordination chemistry? A mechanistic approach.

474 Coordination chemistry reviews 230(1-2): 263-282.

475 Yan JR, Zhou FX, Zhou Y, Wu, XH, Zhu QL, Liu HY, Lu HF(2018) Wet oxidation and absorption procedure for $\mathrm{NO}_{\mathrm{x}}$ removal. Environ Tech Innovation 11: 41-48. Zhang CM, Song W, Ma QL, Xie LJ, Zhang XC, Guo H(2016) Enhancement of $\mathrm{CO}_{2}$ capture on biomass-based carbon from black locust by $\mathrm{KOH}$ activation and ammonia modification. Energy \& Fuels 30(5): 4181-4190.

Zhang D, Huo P, Liu W(2016) Behavior of phenol adsorption on thermal modified activated carbon. Chinese J Chem Eng 24(4): 446-452. nitrite/nitrate formation in limestone slurry for WFGD system. Applied Energy 129(15):187-194. metal ions adsorbed by biomass-activated carbon doped with a solid nitrogen source. RSC Advances 9(64): 37440-37449. FeII-EDTA solution coupled with the FeII-EDTA regeneration catalyzed by activated carbon. Separation and Purification Technology 74(1):1-6.

\section{Declarations}

\section{Ethics approval and consent to participate}

Not applicable

\section{Consent for publication}

Not applicable.

\section{Availability of data and materials}

Not applicable.

\section{Competing interests}

The authors declare that they have no competing interests.

\section{Funding}

Not applicable.

\section{Authors' contributions}

$\mathrm{XD}$ and $\mathrm{PC}$ analyzed the experimental data, and was a major contributor in writing the manuscript.

RZ did the experiments. XL made the experimental plan and finished the manuscript.

All authors read and approved the final manuscript. 
Figures

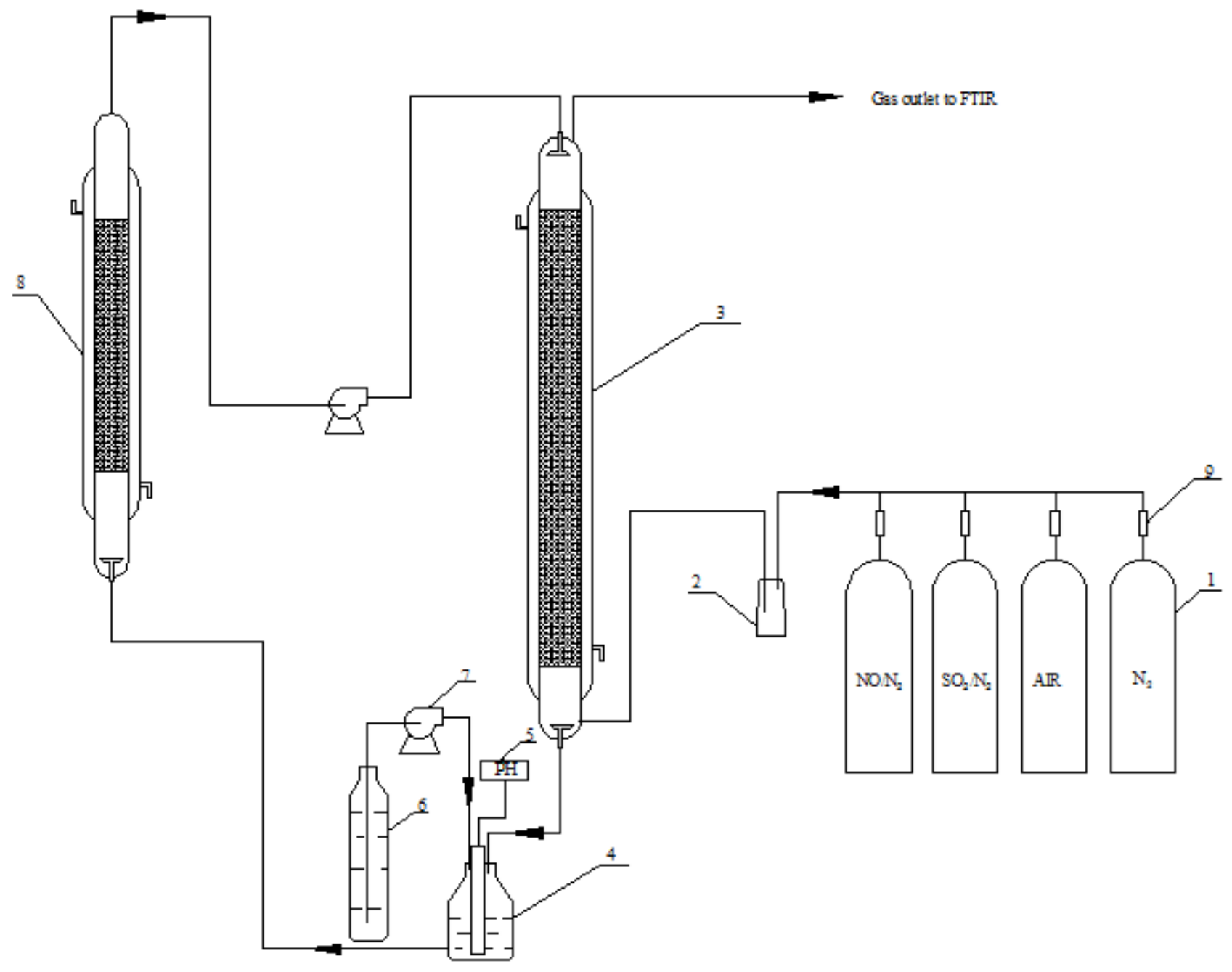

Figure 1

Flowchart of absorption and regeneration reactor system

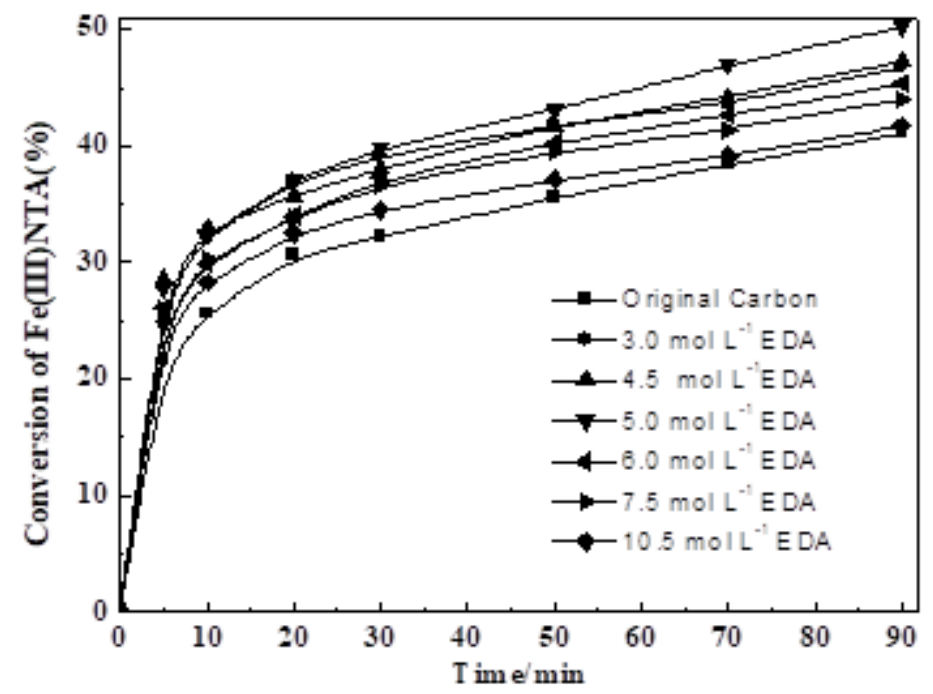

Figure 2 
Effect of the EDA concentration on the catalytic performance of carbon samples

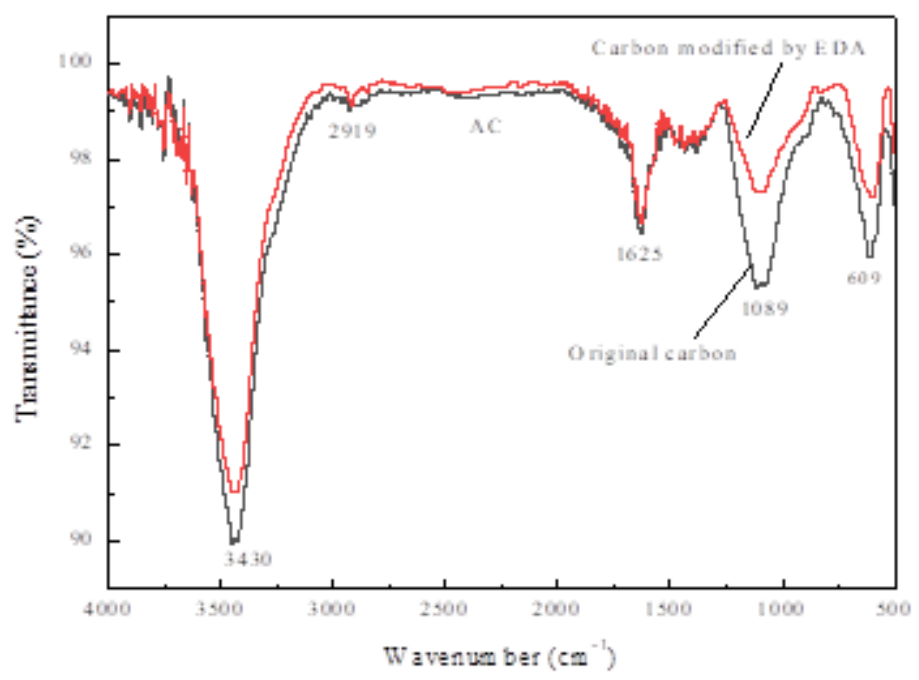

Figure 3

FTIR spectra of original carbon and modified carbon with EDA
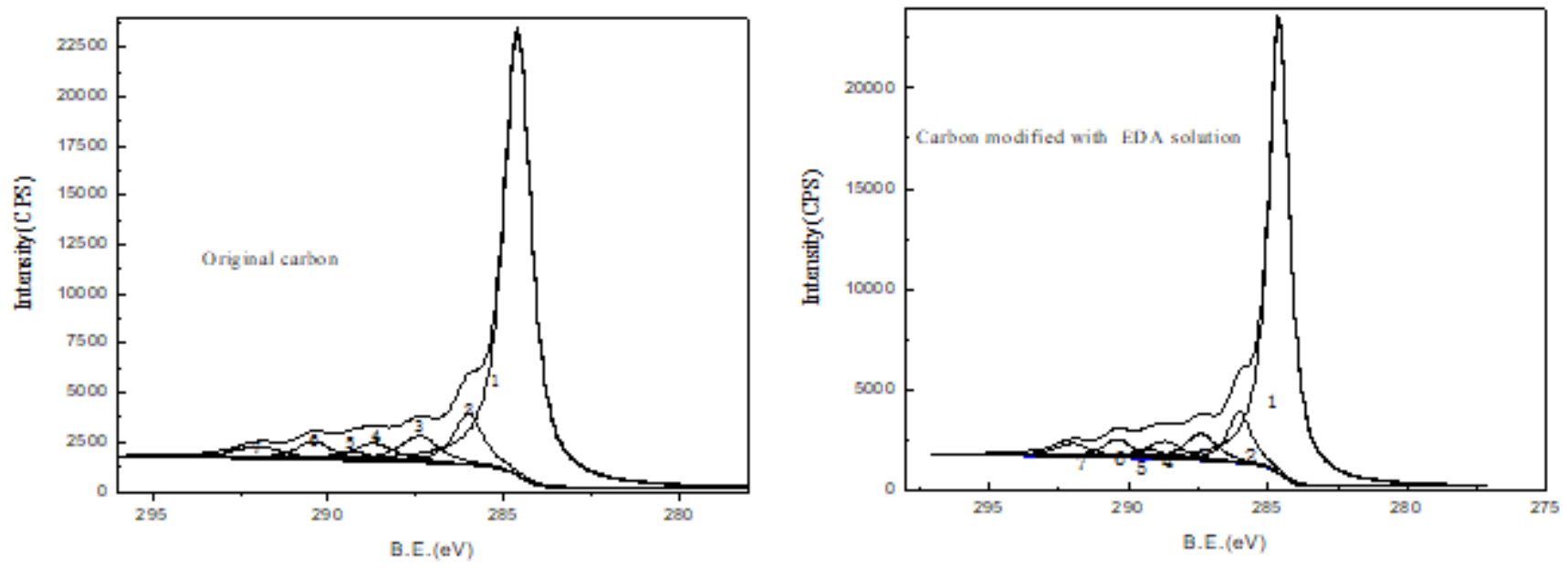

Figure 4

C1s spectra of the original carbon and the modified carbon 

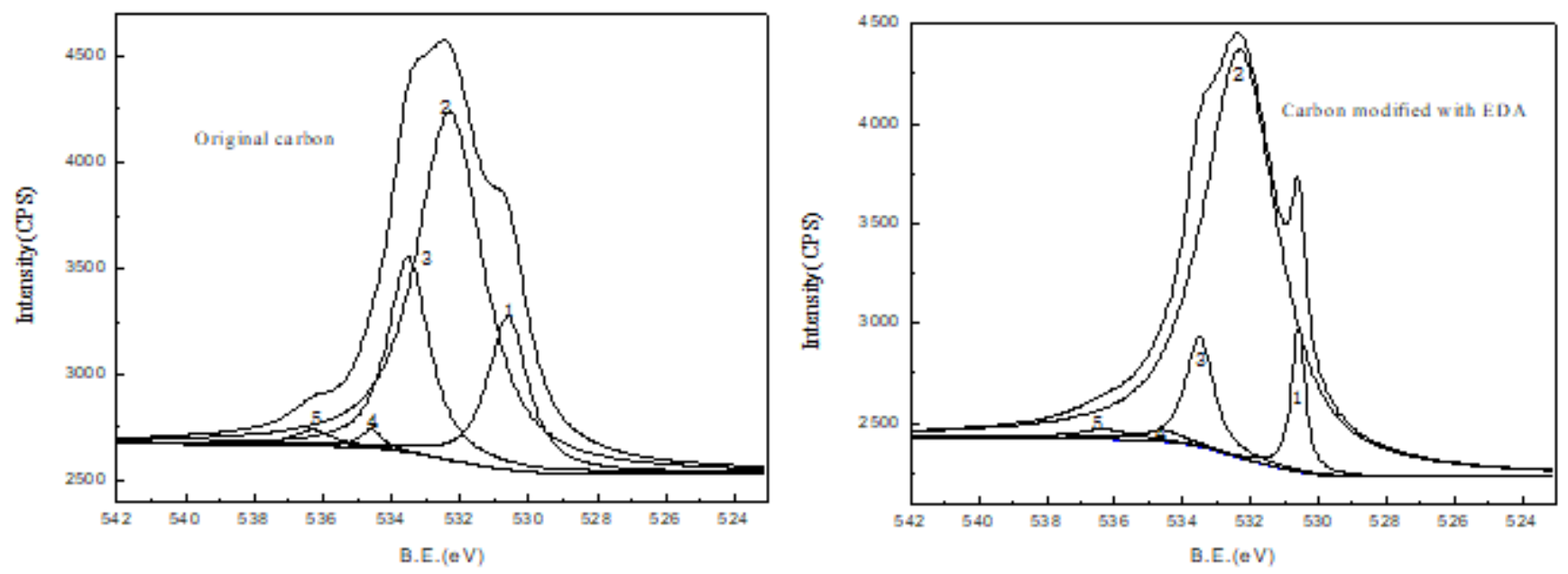

Figure 5

01s spectra of the original carbon and the modified carbon

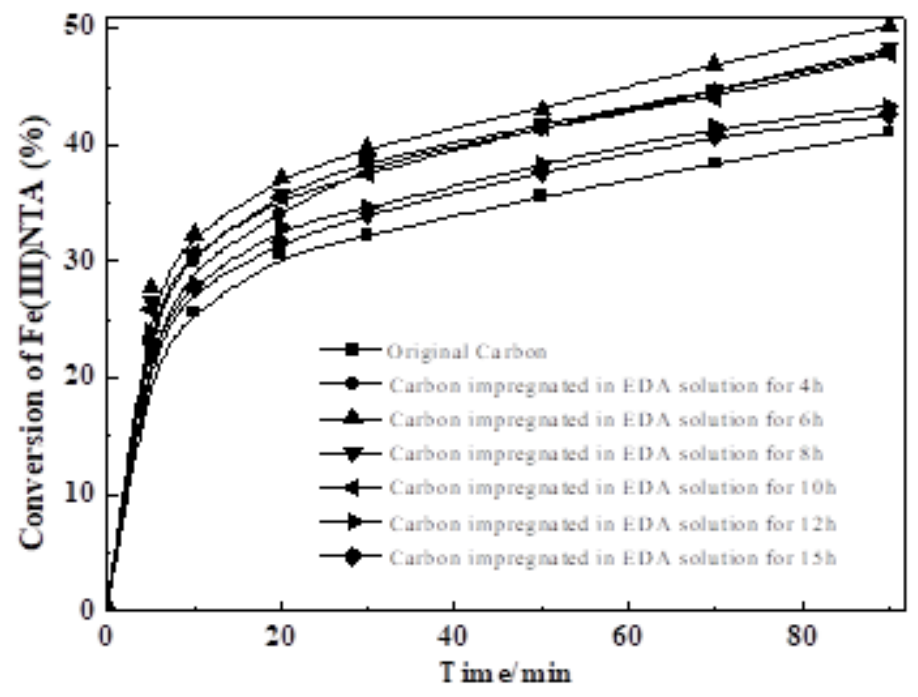

Figure 6

Effect of impregnation time on the catalytic performance of activated carbon 


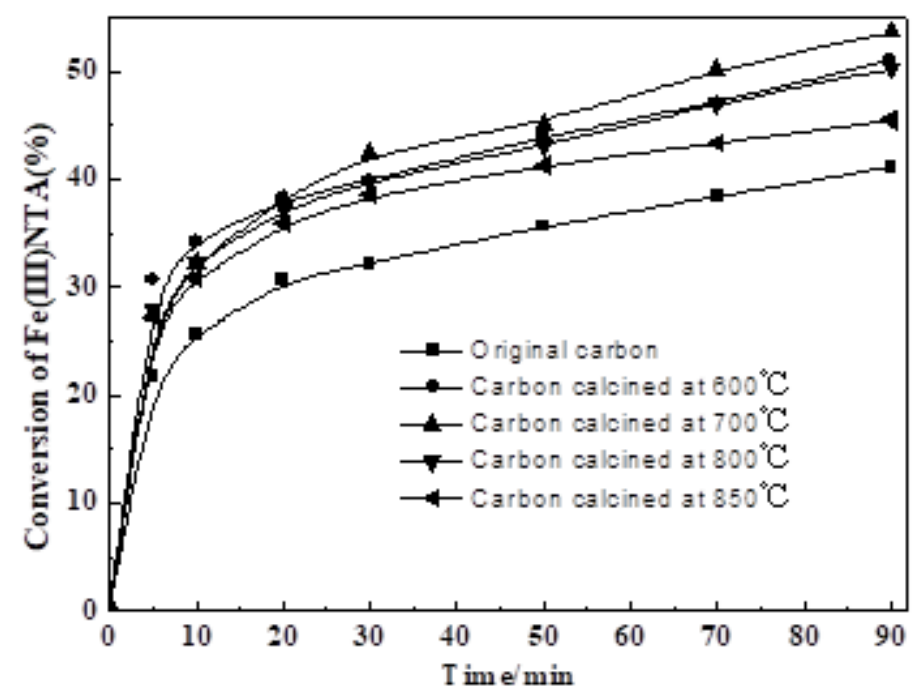

Figure 7

Effect of calcination temperature on the catalytic performance of activated carbon

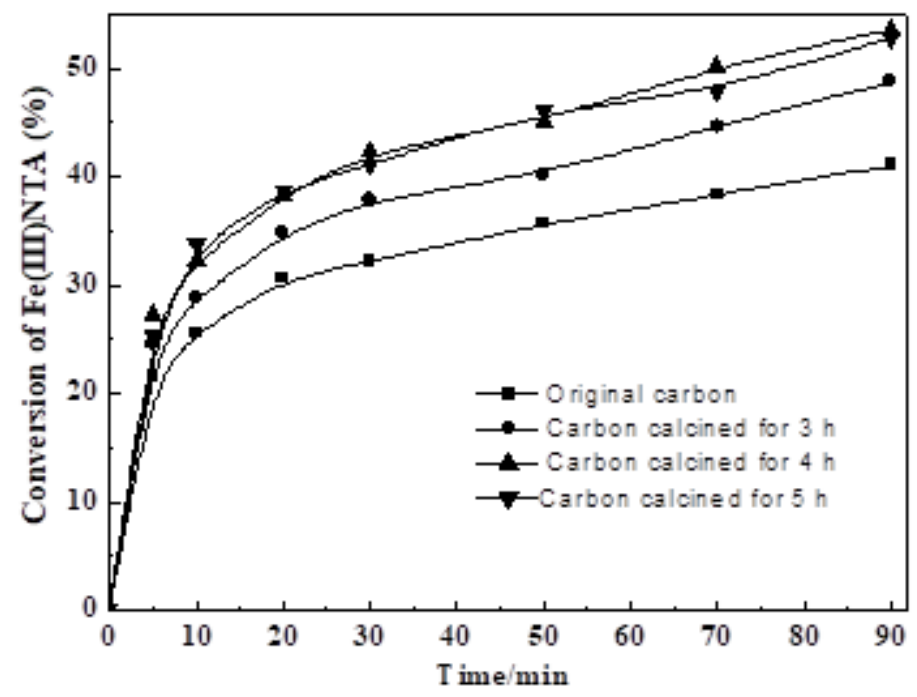

Figure 8

Effect of calcination time on the catalytic performance of activated carbon 


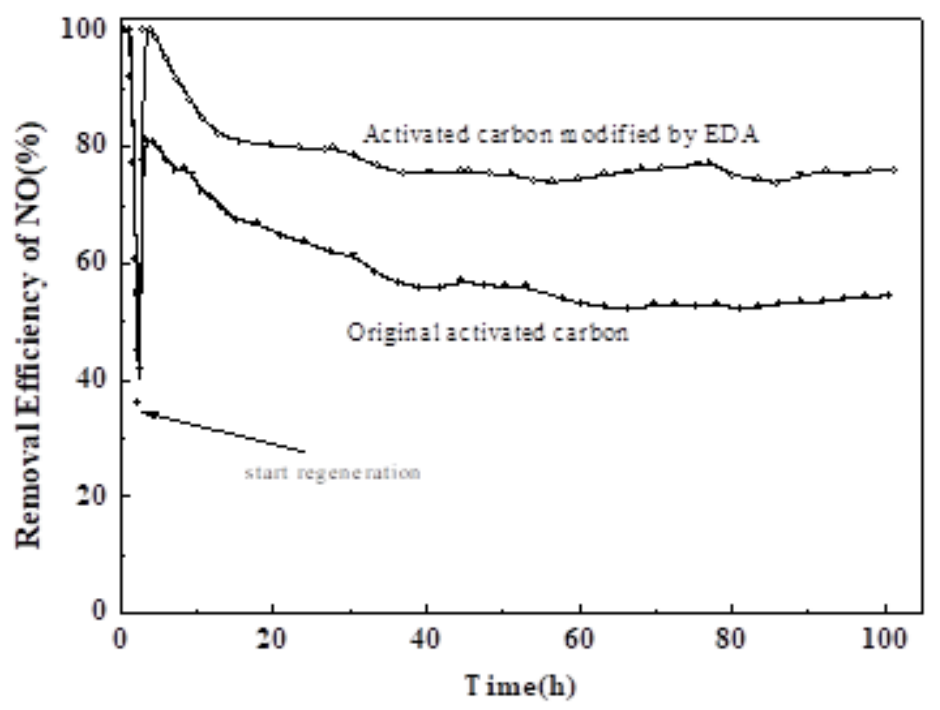

Figure 9

NO removal coupled with Fe(II)NTA- regeneration catalyzed by activated carbon 